\title{
ON THE ANLAGE AND MORPHOGENESIS OF THE CHORDA DORSALIS IN MAMMALIA, IN PARTICU- LAR THE GUINEA PIG (CAVIA COBAYA)
}

\author{
G. CARL HUBER \\ Department of Anatomy, University of Michigan \\ FOURTEEN FIGURES
}

The discussion here undertaken is one which is in no sense foreign to anatomic and morphologic literature; indeed it may be stated that there is perhaps no single subject in vertebrate embryology which has been so frequently and so ably investigated and has formed the basis of such extensive and fundamental speculation, as the subject here under consideration. The discussion of the anlage of the mammalian chorda dorsalis, involves a consideration of the anlage and homologies of the primary germ layers, the question of blastulation and gastrulation, considered ontogenetically and phylogenetically; in a word, the consideration of the embryologic stages immediately following the stages of segmentation. A full consideration of this broad question is beyond the limits of this communication. Neither is it possible to consider here at all completely the extensive literature involved. This seems the less necessary since relatively recently a goodly number of investigators have given extensive and critical reviews of the literature dealing with this question as may be learned on study of certain of the contributions of O. Hertwig, Keibel, Van Beneden, Bonnet, Rabl, Hubrecht and others. I shall, therefore at the outset, limit the scope of this communication by stating that it is the purpose at this time to present observations dealing with the anlage of the mesoderm and chorda dorsalis as noted in the guinea pig, a form especially adapted for the investigation of these problems; as may be learned from the studies of Carius, Liederkühn, 
Keibel, Graf Spee and others, documenting these observations by a series of figures, showing successive stages of development, taken from cross-cut and sagittal series, and to dispense very largely with a consideration of the enticing problems of blastulation and gastrulation as concerns the mammalian ovum, problems and questions which have influenced very greatly the interpretations given by certain investigators to the actual observations as recorded by them. Only a small portion of the literature reviewed, and more especially that relating to mammalia, shall here receive notice, and only as the successive stages discussed by me are given special consideration.

\section{MATERIAL AND METHODS}

The embryological material on which this investigation is based consists of many uninterrupted series, cut in the cross and in the sagittal plane, of developmental stages of the guinea pig, ranging from about the 10th day to the 15th day of development. The material is all of it 'timed'; the ages given extending from time of observed insemination to the time of killing. For fixation I have used almost wholly Carnoy's fluid. After fixation and embedding in paraffine, the sections were cut either by means of the Minot rotary microtome or on a sliding microtome with the aid of the water-on-the-knife method. The sections of the great majority of the series have a thickness of either $5 \mu$ or of $7 \mu$; some few a thickness of $10 \mu$. After sectioning, the series were fixed to slides by means of the wateralbumen method and stained on the slide by means of hemalum and Congo-red. Every embryologist of experience knows that socalled 'timed' embryologic material of mammalia does not insure succession of stages; however, I belicve all will agree that a much more complete series of stages is assured by this method, than when a chance collection is made. My own series though fairly complete lacks preparations covering as completely as might be desired certain stages of development, while other critical stages are covered by an abundance of material. The figures here presented were all drawn at relatively high magnifi- 
cation, with the aid of the camera lucida, and greatly reduced in reproduction. It has seemed to me desirable to present, so far as the size of the preparation permits, for each stage, figures showing cross and sagittal sections of the entire germ disc. A comparison of successive stages is thus greatly facilitated, and it is hoped extensive description obviated. Certain of the germ dises here considered have been reconstructed by Doctor Worcester, Miss Helen L. B. Gage and myself for another study now in progress. These reconstructions have been of great aid in determining respective stages and in determining the relations and relative size of the structures primarily under consideration.

TWO LAYERED GERM DISC OF GUINEA PIG AND ANLAGE OF THE MESODERM

As is well known, the guinea pig belongs to that type of rodents presenting an inversion of germ layers. The phenomenon of segmentation and implantation of the ovum of the guinea pig have been carefully studied by Graf Spee; the question of the inversion of the germ layers, as concerns the guinea pig, by Selenka. From Selenka's account, which concerns us here most particularly, it is learned that the early stages of the blastocyst formation are not unlike similar stages as described by me for the albino rat. It is further learned that for the guinea pig, after the formation of a blastocyst with ectodermal node, visceral layer of entoderm, parietal or transitory ectoderm and ectoplacental cone, a stage corresponding in many respects to a 6 day, 16 hour stage of the albino rat (Huber, fig. 24), the further steps in the inversion differ somewhat from that observed in the albino rat. In the latter the egg cylinder elongates through growth of the extra-embryonic ectoderm, resulting in a solid egg cylinder in which a proamniotic cavity develops secondarily; while in the guinea pig the ectodermal node separates early from its close relation to the base of the ectoplacental cone and there is developed an interamniotic space separating trägerectoderm and ectodermal node, and bounded on the sides by a layer of visceral entoderm. The guinea pig egg cylinder thus 
elongates rapidly. It encloses in its free end, which is the antimesometrial end, a solid nodule of cells, which is here known as the ectodermal node, surrounded almost completely by visceral entoderm, which layer extends to the base of the träger, enclosing the interamniotic cavity. Such as are not familiar with the egg cylinder of the guinea pig of this stage of development I would refer to figure 13, plate XII, of Selenka's studies, copied as figure 590 by $\mathrm{O}$. Hertwig. In the series of figures given

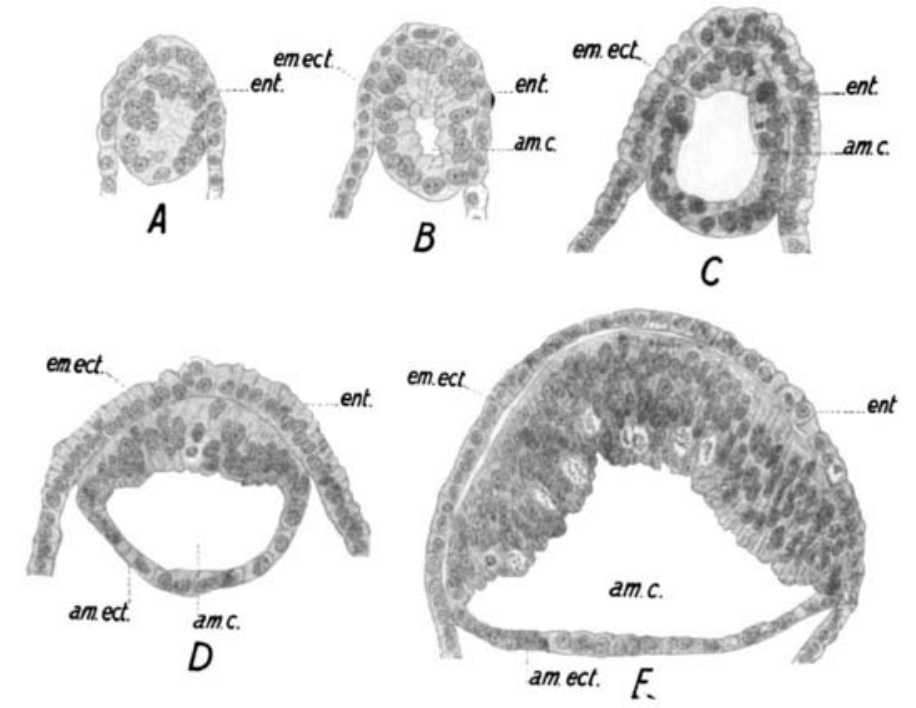

Fig. 1 A to E. A, 10 days, 18 hours stage of $\mathrm{egg}$ cylinder of the guinea pig with ectodermal node showing the very beginning of the amniotic cavity; $\mathrm{B}, 10$ days, 18 hours stage, with ectodermal vesicle with small amniotic cavity; C, 11 days, 18 hours stage, with ectodermal vesicle and amniotic cavity; D, 11 days, 18 hours stage, with differentiation of wall of ectodermal vesicle into primary embryonic ectoderm and amniotic ectoderm; $\mathrm{E}, 10$ days, 18 hours stage, final bilammelar stage. $\times 200$. ent., entoderm; em.ect., embryonic cctoderm; am.c., amniotic cavity; am.ect., amniotic ectoderm.

by me (fig. 1, A to E) covering the ectodermal node and vesicle stages, only the antimesometrial end of the egg cylinder is figured. The relations of the portion of the egg cylinder here figured to the entire egg cylinder of the respective stage, may readily be ascertained by comparing this series of figures with those given by Selenka, to which reference has been made. 
In figure 1, A to E, are presented a series of developmental stages of the guinea pig, giving in close sequence successive stages in the development of the ectodermal node and ectodermal vesicle with closed amniotic cavity and with embryonic and amniotic ectoderm differentiated. In $A$, of figure 1-10 day, 18 hour stage-the entoderm, ent., is found in a single layer almost completely surrounding a nodule consisting of radially arranged cells, the ectodermal nodule, presenting the very beginning of a central cavity. Only in one section of this series was this cavity clearly defined. It represents the anlage of a closed amniotic cavity. This ectodermal nodule occupies the antimesometrial end of the entodermal egg cylinder, much as a marble might occupy the end of the finger of a glove. The space beneath the ectodermal nodule and between the entodermal layer, so far as sketched, in this and in the following four figures of this series, is the interamniotic space, not especially labelled here. Figure 1, B-10 day, 18 hour stage-and figure 1, C11 day, 18 hour stage-follow in close succession of stages, presenting successively a slightly larger amniotic cavity. In figure 1, D-11 day, 18 hour stage - a slight advance in morphogenesis may be observed. The increase in the size of the amniotic cavity is to be noted, more especially the differentiation in the wall of the ectodermal vesicle. That portion of the ectodermal vesicle which is in apposition with the entoderm, presents an ectoderm composed of tall columnar cells with nuclei in several strata, and is recognized as the ectoderm of the embryonic dise, em.ect.; while that portion of the wall of the ectodermal vesicle which separates the amniotic from the interamniotic cavity, consists of relatively thick, flattened cells with nuclei in one layer and is recognized as the amniotic ectoderm, am.ect. The embryonic ectoderm has the form of an inverted watch crystal, and is throughout in close relation to the visceral entoderm. In figure $1, \mathrm{E}$, there is presented the $23 \mathrm{~d}$ of a series of 50 sections, having a thickness of $5 \mu$, passing through the antimesometrial end of an egg cylinder of the guinea pig of a 10 day, 18 hour stage. This series appears to me to represent cross sections of the embryonic disc, though I am unable to as- 
certain with any degree of certainty any definite bilateral symmetry. This stage is readily deduced from the preceding one. The larger amniotic eavity is evident. The embryonic ectoderm forms a thick layer, with nuclei arranged in four to five strata, becoming abruptly thinner as the amniotic ectoderm is reached, which consists of a single layer of thick flattened cells. The embryonic ectoderm is throughout in close relation with the layer of visceral entoderm. This stage may be regarded as presenting the final stage of the bilammelar condition of the germ disc of the guinea pig, the area forming a cup-or-saucer-shaped structure with concavity toward the ectoderm. There is at this stage no trace of mesoderm, ectoderm and entoderm being throughout in close relation.

As concerns the anlage of the mesoderm in the germ disc of the guinea pig, my own series do not give an answer which is not open to question in that none of the germ discs sectioned by me, covering the stages immediately following the bilammelar stage, present the very beginning of mesoderm differentiation. The several germ discs of my series, covering this stage, though ranging over a day in difference of ages, all present a stage of mesoderm development which I can not regard as showing the first appearance of the mesoderm. I am led to believe that the anlage and early spread of the mesoderm in the germ disc of the guinea pig, occupies only a very brief period of time and that it would seem necessary to collect a large series of stages, from the end of the 11th to the beginning of the 12th day of development, to chance on the desired preparations. In the material of the white rat, covering the period of the anlage of the mesodorm, I was more fortunate, in that a number of my preparations cover this stage very satisfactorily. In figures 31 and 32 (Huber) the anlage of the mesoderm in the albino rat is shown in a stage which is slightly younger than the youngest stage showing mesoderm in my guinea pig series. The question of the anlage of the mesoderm in the albino rat was only incidentally touched upon in that publication and will be discussed more fully in a forthcoming monograph in which the development of the albino rat from the 10 th to the 12 th day will be considered. In 
the albino rat, as I have stated on a former occasion, "The anlage of the mesoderm is from the sagittal portion of the caudal region of the primary embryonic ectoderm, the caudal part of the future primitive streak." This statement, in so far as my own series enable me to reach conclusions, is equally applicable to the germ disc of the guinea pig. In figure 2 , there is pre-

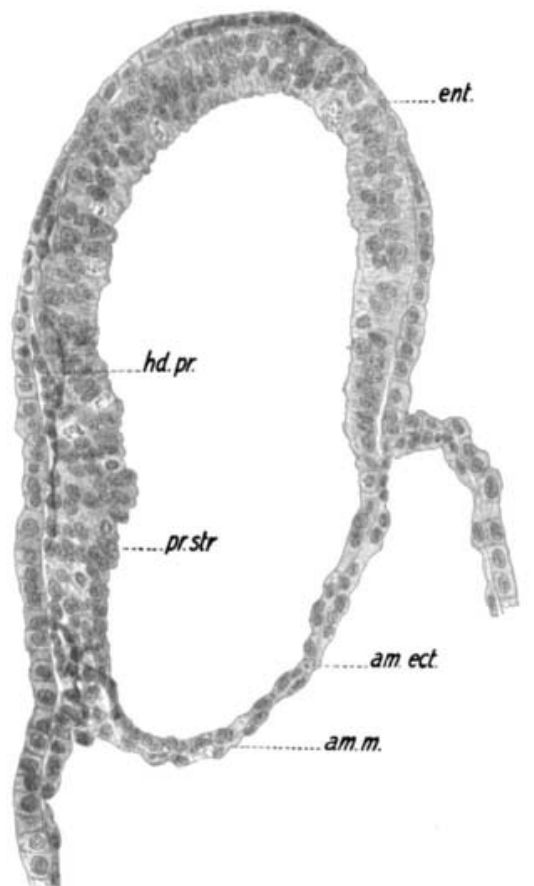

Fig. 2 Germ disc and amniotic vesicle of guinea pig, 12 days and 12 hours after insemination; early stage of mesoderm formation; anlage of head process. $\times 200$. ent., entoderm; $h d . p r$., head process, in anlage; pr.str., primitive streak, in anlage with formation of mesoderm; am.ect., amniotic ectoderm; am.m., amniotic mesoderm.

sented practically the middle section of a series of 58 sections, having $5 \mu$ thickness, and passing approximately through the sagittal plane of a germ disc and amniotic vesicle of a guinea pig of 12 day, 12 hours. Another germ disc, of 11 day and 18 hours, cut in the sagittal plane, though slightly obliquely to the mid axis shows essentially the same stage of development, and still another, having an age of 12 days and 7 hours, is in a stage 
of development which is between that shown in stages $D$ and $\mathrm{E}$, of figure 1 , and is distinctly younger than $\mathrm{E}$, of figure 1 , (10 days, 18 hours). The germ disc and amniotic vesicle shown in figure 2 , is slightly compressed from right to left, as shown in this figure, due to a slight folding of the wall of the interamniotic cavity; however, this, so far as I am able to ascertain, has in no way influenced the relation of its parts, but gives this vesicle a slightly more elongated form than is normal, judging from the appearances presented by several other vesicles or germ dises of essentially the same stage, included in my series. From a study of figure 2, it may be observed that the outer layer of visceral entoderm forms a continuous layer, consisting of a single layer of short cuboidal or slightly flattened cells, distinctly separated as an uninterrupted and continuous layer over the entire extent of the primary embryonic ectoderm and continues into the entodermal layer forming the wall of the interamniotic cavity. Very few mitotic figures are observed in the entodermal layer; one is shown to the left in this figure. The primary embryonic ectoderm is relatively thinner than in the preceding stage described (E, fig. 1), showing two or three strata of nuclei, reduced to a single stratum of nuclei at its transition to the amniotic ectoderm, which latter extends as a single layer of flattened cells over the inner face of the amnion. Especial attention is drawn to the embryonic ectoderm of the future caudal region of this germ disc, the future primitive streak region, pr.str., to the left of this figure. Very active mitosis is observed in this region and it will be noted that the sharp contour of the outer surface of the cctoderm is here lost. A migration of ectodermal cells is here noted, evidenced by the arrangement of the nuclei. The migrating cells constitute the primary mesodermal cells. As clearly seen in this section through the mid sagittal plane, certain of the cells derived from the ectoderm wander cephalad between the primary embryonic ectoderm and visceral entoderm, and are distinctly and easily separable, from both ectoderm and entoderm. This group or process of cells, derived from the ectoderm, is regarded as the anlage of the head process. If the series of sections is traced in both directions from 
the mid sagittal section drawn in figure 2 , it will be noted that the primary mesodermal cells have spread out on both sides of the mid axis to a little over half the circumference of this vesicle. The future head region and to the extent of about half of the spread of the primary embryonic ectoderm, is at this stage still free from the invasion of the mesodermal cells. The mesoderm of the germ disc of the guinea pig, as this series seems to indicate, though a slightly younger stage would perhaps present more conclusive evidence, has its anlage in the sagittal portion of the primary embryonic ectoderm and is clearly a derivative of the primary embryonic ectoderm of this region. The rapid spread of the mesoderm over the interamniotic cavity face of the amniotic ectoderm, is clearly shown in these preparations. In this vesicle the entire amnion consists of two layers of cells, one amniotic ectoderm, the other mesoderm, both in single layer. That the spread of the mesoderm over the amniotic ectoderm is from the caudal region of the germ disc is perhaps evidenced by the fact that the cephalic end of the germ disc is as yet free from mesoderm, see to the right of figure 2. The mesoderm extends also along the inner face of the entoderm bounding the interamniotic cavity, to approximately half the length of this cavity. There is no indication that the entoderm bounding the interamniotic space contributes to the formation of the mesoderm. At this stage, the mesodermal cells of the interamniotic space are in a single layer.

On comparison of my own account of the anlage of the germ disc of the guinea pig with that given by Selenka, it will be observed that the two accounts differ very materially. Selenka's account of the anlage of the primitive groove reads as follows:

Was zunächst die Primitivrinne selbst anbelangt, so tritt dieselbe aus als napfartige, randständige Aussackung der Ektodermblase; sie wächst sodann zu einem langen und breiten abgeplatteten Blindsacke aus, welcher sich an der Wand des Entodermmantels hinabzieht. Schr bald verkürzt sich dieser Blindsack, dessen Lumen der Primitivrinne der übrigen Amnioten entspricht, um am 13 Tage, also etwa zwei Tage nach seiner Entstehung, sich wieder zu einer napfförmigen Grube zu verkürzen und bald darauf gänzlich zuverstreichen.

Noch eho die blindsackförmige "Primitivrinne" ihre maximale Grösse erreicht hat, beginnt die Bildung des Mesoderms. Ihrer gan- 
zen Länge nach treten aus dem dem Entodermmantel zunächst gelegenen Theile ihrer Wandung vereinzelte Mesodermzellen aus, von denen etliche, in meinen Präparaten mit Ausläufern versehene, in der Richtung nach der Basis des Keimcylinders zu sich fortschieben, während vereinzelte andere rechts und links an der Innenseite des Entoderms fortwandern, wie ich aus Quer-und Längsschnitten mit genügender Sicherheit erschliesse.

It is possible that I have missed this transitory outpocketing of the amniotic cavity which gives rise to the primitive groove and the primary mesoderm. However, in the stage described in figure 2, no distinct primitive groove is as yet recognizable, the primitive groove developing at a much later stage. The region of the primitive streak I have recognized in the stage described. It is possible that Selenka was led astray by reason of limited material, and has interpreted an artefact, due to folding of the vesicle, as a structure of consequence. Selenka's figures are difficult to judge critically in that they all appear to be more or less diagrammatic. Figure 20, plate XIII, for instance, may represent a stage which is comparable to that given in my own figure 2, however, in Selenka's figure there is no indication of the participation of the ectoderm of the caudal region in mesoderm formation; no anlage of head process and the cephalic end (?) of the embryonic disc is well invaded by mesoderm. This figure of Selenka's suggests that he has drawn a frontal section of this stage as a sagittal section, viewed in this light, it becomes intelligible. Neither Lieberkühn nor Keibel consider especially stages of the development of the mesoderm in the guinea pig of as early a stage as shown in figure 2 .

A study of the literature, comprising both original sources and the more recent comprehensive reviews, reveals the fact that the majority of the more recent observers are agreed, so far as concerns mammalia, in regarding the mesoderm as a derivative of the embryonic ectoderm. O. Hertwig after discussing this question very fully in his account of the germ layers, expresses himself as follows:

Hinsichtlich des Ursprunges des mittleren Keimblattes bei den Säugetieren stimmens jetzt wohl, von einzelnen Ausnahmen abgesehen, alle Beobachter der Darstellung bei, welche zucrst Kölliker gegeben 
hat. Danach ist die Bildungsstätte des mittleren Keimblattes, wie bei den Vögeln, einzig und allein der Hensen'sche Knoten, der Primitivstreifen und der Caudalwulst, also der Bezirk, in dessen Bereich ein Zusammenhang mit dem äusseren Keimblatt stattfinded und, wie leicht festzustellen ist, sich auch zahlreiche Teilungsfiguren nachweisen lassen, welche ein Rückschluss auf eine sehr lebhafte Zellvermehrung an diesem Orte zulassen.

My own views concerning this question are expressed in one of the summaries found in Keibel's article on the development of the pig. This reads as follows and summarizes my own observations on the origin of the mesoderm in the guinea pig:

"Eine andere Quelle des Mesoderms als der Primitivstreifen liess sich beim Schweine nicht nachweisen; von einem peripheren Mesoblastkeim konnten trotz genauer Nachforschung $k$ ine Spuren entdeckt werden."

For stages following the stage showing the anlage and early spread of the mesoderm, my own material is very complete; the series at hand showing successive stages of development ranging at relatively close intervals. For the special discussion of a stage closely following that shown in figure 2, we shall consider two germ discs taken from the same uterine horn 13 days, 1 hour after insemination, and presenting almost identical stage of development. Four other germ discs, taken from the same uterus, 12 days, 16 hours after insemination, two cut in cross sections and two in the sagittal plane, are of essentially the same stage of development. The germ discs to be considered now, are only a few hours older than that described in connection with figure 2 . It is necessary to call attention to the fact, that in the figures following it was deemed desirable to give the respective figures such position as would bring the entodermal layer on the under side, with amnion and ectoderm above, thus in a sense inverting the figures when compared with those shown in figures 1 and 2 , and when thought of as in normal position at the antimesometrial end of a large, broad egg cylinder. In the egg cylinder as found in place in the uterus, the träger or ectoplacental cone is directed toward the mesometrial border, while the germ disc or embryonic area, which has the form of a porcelain evaporating dish, capping the egg cylinder, is directed 
toward the antimesometrial border of the uterine tube, with the visceral entoderm as its outer layer. The diagrammatic figures of Selenka (figs. 22 to 25 , plate XIII) may serve to make this clear. In figure $3, \mathrm{~A}$ to $\mathrm{D}$, are presented drawings of a number of cross sections, taken through the antimesometrial end of an egg cylinder of the guinea pig removed 13 days, 1 hour after insemination. The series includes 90 sections of $7 \mu$ thickness, in which the germ dise is included. This germ dise or embryonic area has the form of an inverted porcelain evaporating dish. Approximately the first twenty and the last twenty sections of the series, including the embryonic area, do not present cross, but tangential sections of the epithelial layers of the area. However, their interpretation presents no special difficulty, especially when studied under the mon-objective binocular, which I have found of great service in determining relations. This embryonic area presents a shallow primitive groove which extends about half the length of the area, the anlage of a head process, with mesoderm well developed in the caudal half of the embryonic area, and cephalad along the borders of the area, but presents a mesoderm free portion cephalad to the head process. This the following series of drawings may serve to make clear. In $A$ (fig. 3) is presented the 16 th section, counting from the cephalic border of the embryonic area. It will be noted that the entoderm under nearly the entire extent of the embryonic ectoderm is present in single layer of flattened cells, these becoming gradually taller as the interamniotic cavity is approached. The amnion consists of two layers of cells; a layer of flattened amniotic ectodermal cells and a layer of mesodermal cells. The embryonic ectoderm, to very near the border of attachment of the amnion, presents a relatively thick stratum of cells with nuclei in perhaps four layers and is bounded on its outer or under surface by a distinct membrana prima or basement membrane, uninterrupted through its entire extent. No mesodermal cells are to be observed between the ectoderm and entoderm throughout the greater extent of the section. The mesoderm has invaded the area for a short distance along its borders; along the attachment of the amnion. That these mesodermal wings 


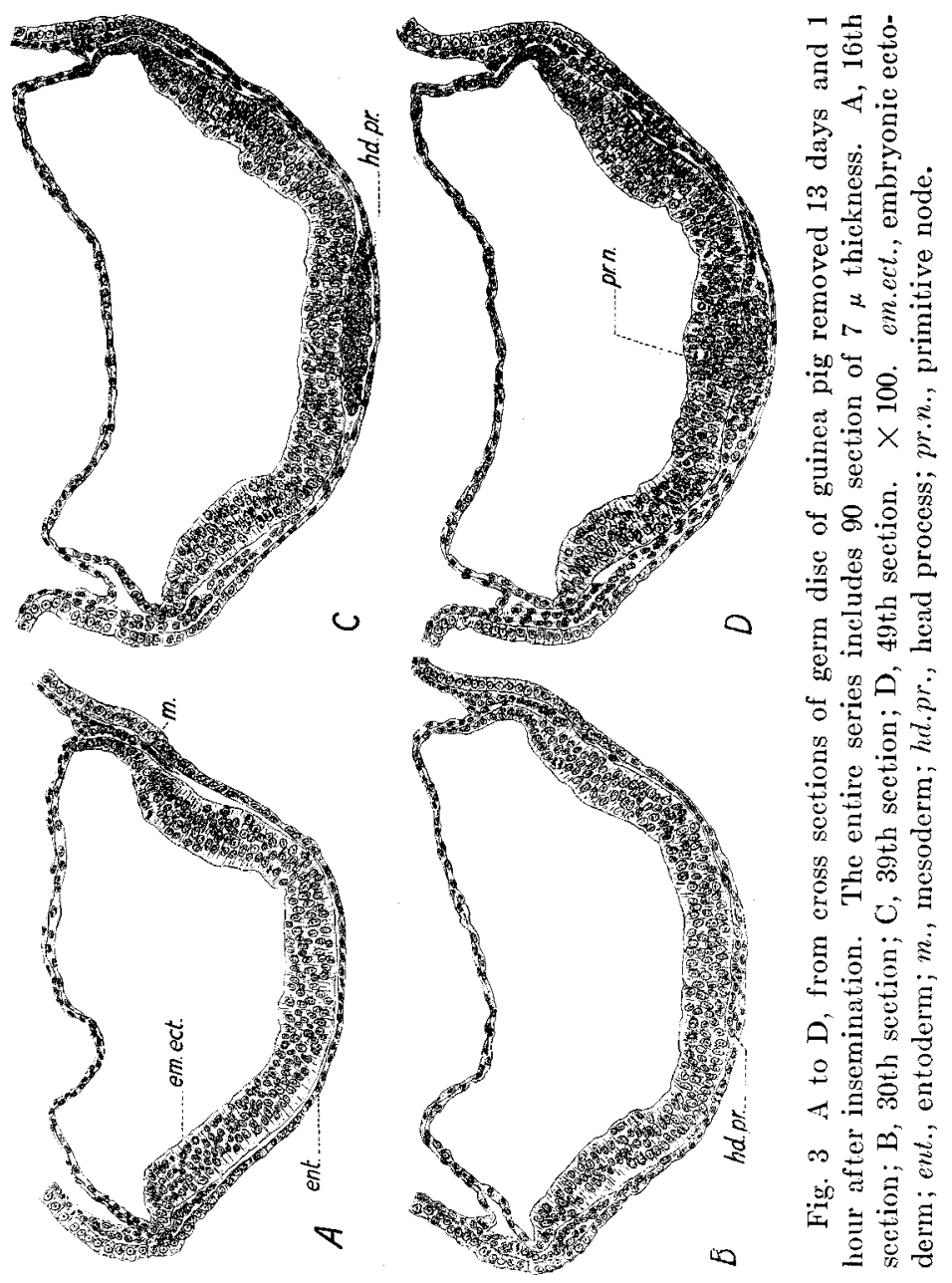


are not developed in situ is perhaps evident from their relation to the ectoderm and entoderm, and may be deduced from the fairly active mitosis noted in the mesodermal cells. On tracing the sections toward the caudal portion of this area, these lateral wings of mesoderm are traceable to the mesoderm of the primitive streak region. As the series is followed caudalward, two cells are observed in the axial portion of the embryonic area, between ectoderm and entoderm in the 28th section, and in B (fig. 3 ) is presented a drawing of the 30th section of the area. This differs from that shown in $\mathrm{A}$, of this figure, in that there is observed a distinct band of cells in the axial portion of the area, situated between ectoderm and entoderm. This band of cells is readily separable from both ectoderm and entoderm, but is continuous with the cells constituting the head process and is here regarded as forming the most cephalad portion of the head process. To each side of this band of head process cells are found a few scattered mesodermal cells; a continuous layer of mesoderm being observed only near the borders of the embryonic area. The cells derived from the ectoderm in the region of the primitive streak, it would appear, invade the cephalic portion of the embryonic area in three main streams; in the axial portion as the cells of the head process and along the borders of the embryonic area as lateral wings of mesoderm. The scattered mesodermal cells observed here and there, I would regard as sprouts of the syncytial mesoderm, cut in cross section. Tsukaguchi, who has recently given an account of the early developmental stages of the goat, gives three regions of mesoderm formation:

"1. am Schildrande, 2. am Primitivstreifen, 3. höchst wahrscheinlich im mittleren Schildbezirk zerstreut."

The section here figured ( $\mathrm{B}$, fig. 3 ), seems to confirm this conclusion. We differ in the interpretation of the appearances present in our respective sections. The ectoderm and entoderm of this figure are as described in the former figure. Attention is called to the two mitotic figures found in the entoderm; one immediately under the cells of the head process. Mitotic figures in the entodermal cells are rare. There is no evidence that they contribute to mesoderm formation. C (fig. 3) reproduces a 
drawing of the 39 th section of this series. In the axial region of the embryonic area there may be observed a spindle shaped group of cells constituting a well developed head process. This group of cells is still distinctly separated from the ectoderm by an unbroken membrana prima, or basement membrane, and is only in contiguity with the entoderm of this region and is as yet not in distinct continuity with the lateral wings of the mesoderm, although these now encroach on the more central portion of the embryonic area. The cells of the head process present as yet no definite grouping and mitotic figures amongst them are not infrequently met with. In the fourth section further caudalward the cells of the head process become continuous with the ectoderm in the mid sagittal plane, as may be observed on a study of $\mathrm{D}$ (fig. 3), which reproduces the 49 th section of this series and may be regarded as passing through the center of Hensen's node or the primitive node region. In the mid axial plane region of this area the ectoderm presents unusual growth activity as evidenced by the number of the mitotic figures. The membrana prima or basement membrane is in this region absent, the cells of the head process being in direct continuity with the cells of the ectoderm. The direction of the long axis of the nuclei of this region indicates an outwandering of the ectodermal cells into the head process. The derivation of the cells of the head process from the ectodermal cells of the cephalic portion of the primitive streak region, the region known as Hensen's node or primitive node is thus evidenced. It will be noted that there is here no indication of an infolding of the ectoderm to form the head process, but evidence of cell migration from the under surface of the ectoderm. The cells of the head process are in this region continuous with the mesodermal cells, this continuity is attained in the $43 \mathrm{~d}$ section of this series. A few sections more caudal than that shown in $\mathrm{D}$, of this figure, a shallow primitive groove becomes evident, which extends to near the caudal border of this area. Along its entire length the mesoderm and the ectodern are in continuity, the membrana prima becoming evident a little to each side of the primitive groove. Active participation of the ectoderm of the primitive streak region in mesoderm formation is to be noted. 
In figure 4 , is presented a drawing of the 40 th section of a series of 87 sagittal sections, having a thickness of $7 \mu$, passing through an embryonic area of the guinea pig 13 day, 1 hour after insemination. In this figure, the caudal end of this area is directed toward the left. This area is practically of the same stage of development as that discussed under figure 3 . The plane of section was not exactly parallel with the mid sagittal plane, but very nearly so. A little study of figure 4 will enable the reader to place approximately the regions of the four cross sections drawn for figure 3 ; to facilitate this I have indicated their approximate position by four crosses. Especial attention

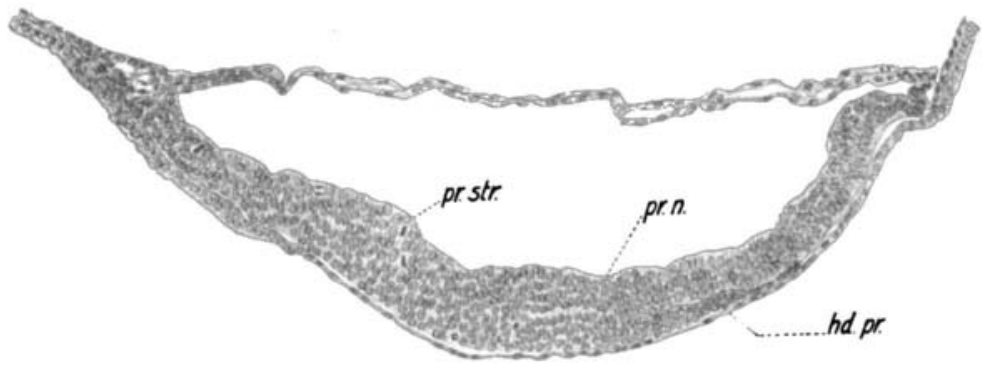

Fig. 4 The 40 th section of a series of 87 sagittal sections of $7 \mu$ thickness of an embryonic disc of the guinea pig removed 13 days and 1 hour after insemination. $\times 100$. Cephalic end of embryonic shield directed toward the right. The crosses placed beneath the figure indicate the approximate level of the sections drawn for $\mathrm{A}$ to $\mathrm{D}$ of figure 3 . $m$. st $r$, primitive streak region; $m, n$, primitive node; $h d . p m$, head process.

is called to the head process as shown in this figure. It will be observed that the mesoderm of the caudal end-left side of figure-of this area, in the primitive streak region, is in direct continuity with the ectoderm. A little cephalad to the middle of the area, the membrana prima or basal limiting membrane, appears under the ectoderm. Just caudal to this region the cells of the head process are in direct continuity with the ectoderm of the primitive node region. The head process, thick at its caudal end, becomes gradually thinner cephalad, ultimately to be reduced to a single layer of cells. Throughout its entire extent, the head process is merely in contiguity with the ectodermal 
and entodermal layers. The cephalic end of the embryonic area for a distance nearly one-fourth the length of the area, presents no cells between the ectoderm and entoderm. It will be observed that the entoderm over nearly the whole extent of the embryonic area is reduced to a single layer of flattened cells; these becoming gradually taller as the cephalic and caudal ends of the area are reached. In sections found each side of the mid sagittal plane, about 5 to 8 sections to the side of the section sketched, the mesoderm extends practically the whole length of the embryonic area and is distinctly separable from the ectoderm and entoderm. In figure 5 , there is presented another section taken in the sagittal plane, showing head process. The respective embryonic area was taken from the uterus 13 days, $23 \frac{1}{2}$ hours after insemination, was cut in sagittal sections of $7 \mu$ thickness of which 126 fall to the embryonic area. The direction of the sections is not exactly parallel to the mid sagittal axis, though very nearly so. The figure reproduces a drawing of the 65th section, and presents a stage of development which is only very little older than that shown in figure 4 . In figure 5 , the cephalic end of the area is directed toward the bottom of the page, at the extreme top of the figure there may be observed the anlage of the allantois, just caudal to the amnion attachment, indicating a slight advance in development over that shown in figure 4. In the stage now under discussion, the primitive streak region extends more than half the length of the embryonic area, as may be clearly noted on study of figure 5; the primitive streak presenting at this stage of development its greatest relative length. My own series of guinea pig embryonic areas contains no preparation in which the primitive streak extends the entire length of the embryonic area, neither have I observed such a stage in the very complete series of albino rat embryos at my disposal, a stage which Keibel has described for the pig. I question, therefore, whether the guinea pig presents a stage in which the primitive streak extends the entire length of the embryonic area. In the stage here under discussion, a free head process is well developed and extends in the mid sagittal plane to very near the cephalic limits of the embryonic area 


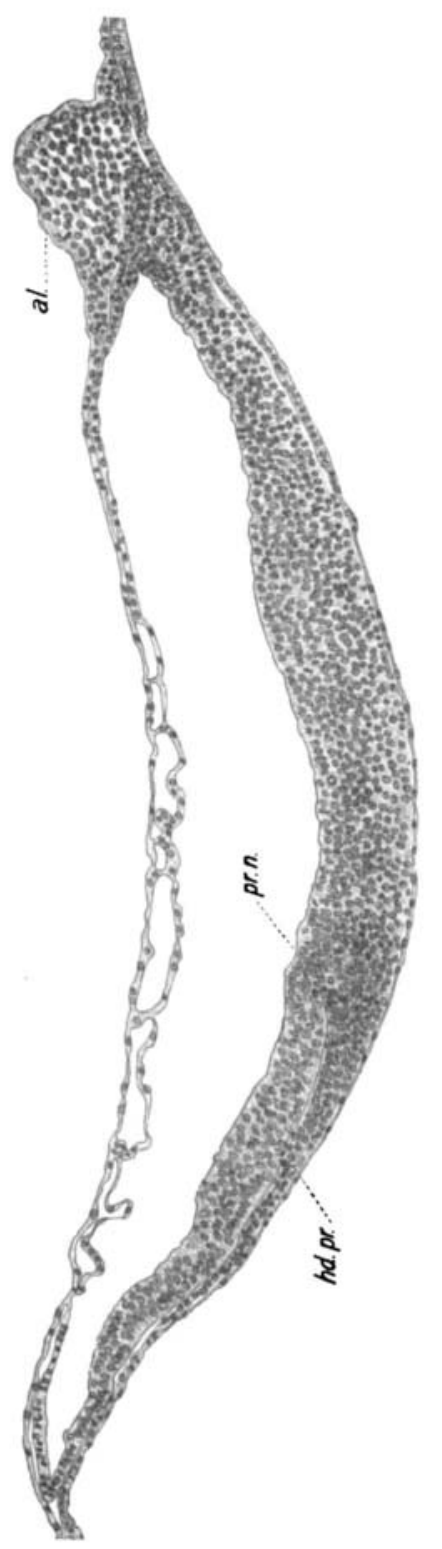

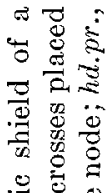

当 0

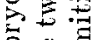

है

สี

$\approx \times \because$

$\sim \dot{\vec{g}}$

吃些

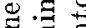

용

बि

.

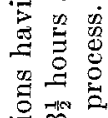

可

串

要雭量

ज्ञ

of

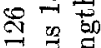

फ 3

㐘苛

焉

虫

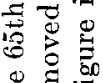

\&

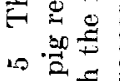

si 궁

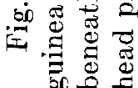


proper. The region of its cephalic end is indicated in the figure by a cross as is also the region of the primitive node, the two crosses being placed just below the entoderm, the region embraced between them indicating the length of the head process. In this figure, the wedge shaped mass of cells constituting the head process, is distinctly separable from both ectoderm and entoderm; from the ectoderm through a distinct limiting membrane found on its under or outer surface, from the entoderm, while in close contiguity to it, it is still not incorporated in it, the entoderm extending as an uninterrupted layer, composed of relatively thin, flattened cells along nearly the entire length of the embryonic area, in the mid sagittal region. In the region of the primitive node, which region extends through 12 sections in this series, the caudal end of the head process is in intimate relation with the ectoderm; the relatively active mitosis of the region, indicating a growth zone for the cells of the head process. Cephalad to the end of the head process there is found a small area in which at this stage the entodermal cells are slightly thicker and where ectoderm and entoderm are not separated by intervening cells. This small area I have regarded as approximately the region of the future primary pharyngeal membrane or oral plate. Cephalad to this area there may be observed in this section a few mesodermal cells. These, it would appear to me, have invaded this region from the lateral wings of mesoderm, which have by this stage grown forward along the borders of the embryonic area to reach its cephalic portion. This region is regarded as that in which the pericardial space develops. If $\mathrm{my}$ interpretations of relations in front of the cephalic end of the head process at this stage be accepted, it will be observed that the head process extends cephalad to approximately the region of the future primary pharyngeal membrane or, oral plate, hus obviating the necessity of postulating a 'replacement plate''Ergänzungsplatte' - of entodermal origin such as Bonnet has described for the dog, a structure which I have not observed in the guinea pig. A free head process, such as here described for the guinea pig has been observed in a number of mammals; by Lieberkühn, Strahl, Carius and Keibel for the guinea pig, by 
Kölliker and Rabl for the rabbit, by Keibel for the pig, by Bonnet for the sheep and dog, by Van Beneden for the bat and by Tsukaguchi for the goat. Keibel who has investigated the guinea pig with reference to the anlage of the chorda dorsalis, speaks as follows concerning the development of the head process in this form:

Vom Henschen'schen Knoten aus wächst nun eranialwärts der Kopffortsatz. Der Kopffortsatz aber liegt hier zunächst vollkommen frei zwischen Ectoblast und Entoblast, wie denn in diesem Stadium überhaupt an keiner Stelle des Meerschweincheneies ein Zusammenhang von Mesoblast und Entoblast annehmbar erscheint. Die Bilder sprechen hier so deutlich, dass man jeden Gedanken daran sofort von sich weisen kann. . . . . Der Kopffortsatz ist ausschliesslich vom Mesoblast gebildet, und obwohl manche Forschen angeben, dass derselbe mit dem Entoblast innig verlöthet sci und an dieser Stelle der Entoblast wirklich mesoblastische Zellen bildet, so konnte ich mich doch nicht überzeugen, dass die platten Entoblastzellen die passive Rolle einer Bekleidung des mesoblastischen Kopffortsatzes aufgäben, um active an seinem Wachsthum sich zu betheiligen.

Keibel states here very correctly the origin and the relations of the head process, but speaks of it as developed from the mesoderm. I would consider the head process as also the mesoderm as a direct derivative of the ectoderm, a view which will receive further discussion in subsequent pages.

The stage of a free head process is followed by one in which the entoderm comes in very close relations with the under or ventral surface of this process and the under surface of the cell mass constituting the primitive node region. An actual fusion of the head process and the mesoderm of the primitive node region with the entoderm, in the sense that the caudal end of the head process and the mesoderm are fused with the ectoderm of this region, does not obtain; the entoderm extending as a continuous membrane, composed of very much flattened cells, along the axial portion of the embryonic area, readily distinguished from the overlying cells in all sections passing through this region, whether cut in the cross or sagittal planes. At this stage, the cells of the caudal end of the head process present an important rearrangement. Those dorsally placed assume a more regular arrangement and an epithelioid character and a narrow 
space is differentiated beneath them; the caudal end of the head process assuming the form of a compressed column of cells, its cells presenting radial arrangement about a narrow central lumen. This differentiation leads to the formation of a structure long known as the chordal canal, which constitutes an important phase in the anlage and morphogenesis of the chorda dorsalis. In figure $6, \mathrm{~A}$ to $\mathrm{D}$, there are reproduced a series of drawings of sections of an embryonic area of guinea pig, re-
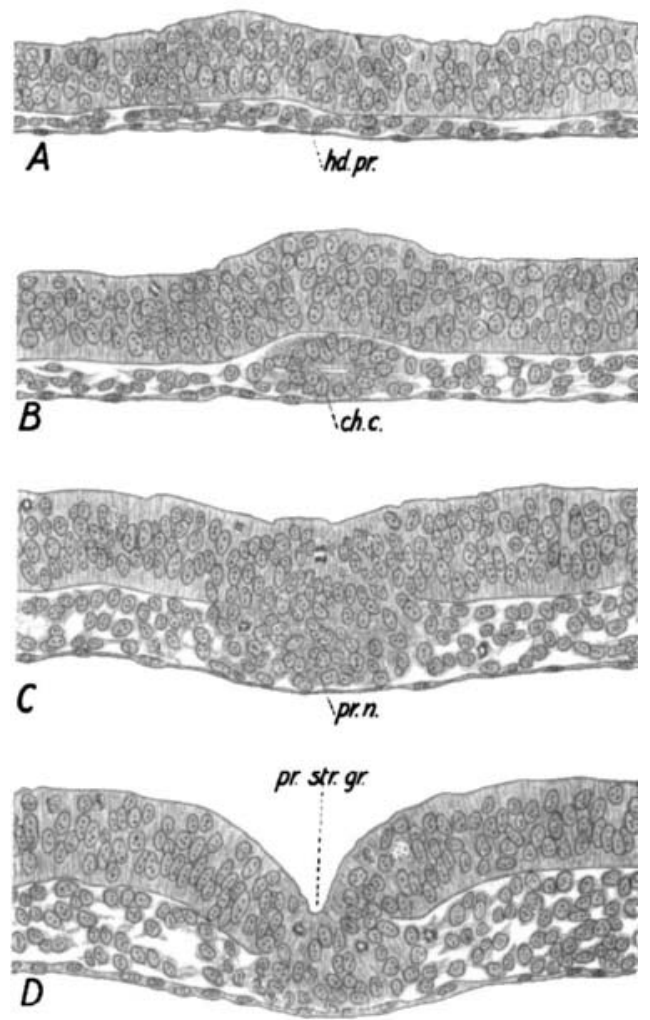

Fig. 6 A to $\mathrm{D}$, from cross sections of an embryonic shield of the guinea pig, removed 13 days and 12 hours after insemination; showing early stages of chordal canal formation. The entire series embraces 160 sections having $7 \mu$ thickness. $\times 200$. A, 35th section, through head process, $B, 53$ rd section, through chordal eanal, C, 84th section, through region of the primitive node, D, 106th section, through primitive streak and primitive groove. hd.pr., head process; ch.c., chordal canal; pr.n., primitive node; pr.str.gr., region of primitive streak and primitive groove. 
moved 13 days and $11 \frac{1}{2}$ hours after insemination, showing early stages in the development and differentiation of the chordal canal. This series, cut cross-wise, embraces 160 sections of $7 \mu$ thickness, extending from amnion attachment of the cephalic border to amnion attachment at the caudal border. This embryonic area presents a very well developed primitive streak and groove, extending a little over half the length of the embryonic area as also a well developed primitive node. The mesoderm is spread over the entire extent of the embryonic area except in the region of the chordal canal and the head process and the oral plate region. In the ectoderm the medullary plate has obtained outline in approximately the cephalic half of the area. On tracing this series from the cephalic amnion attachment, it will be observed that a definite thickening of the ectoderm in the more central portion of the sections appears in the 16th section and the first trace of the cephalic end of the head process are to be noted in the $22 \mathrm{~d}$ section. In A (fig. 6) is reproduced a drawing of the 35 th section of this series. In the region through which this section passes, the head process consists of two layers of compactly arranged cells, occupying the axial region of the embryonic area, and situated between ectoderm and entoderm, readily separable from each of these layers. The mesoderm of this region approaches the borders of this plate of process cells. The entoderm extends as a continuous layer, consisting of very flat and thin cells, ventral to this plate of head process cells. In the ectoderm the medullary plate is recognized as consisting of a thickened layer of ectodermal cells, with nuclei in three strata, and bounded on its ventral surface by a distinct limiting membrane. As this series is traced caudalward the first traces of a chordal canal are to be observed in the 46 th section, the head process being in this section somewhat thicker than that shown in $A$, of this figure, though as yet presenting the form of a flat, spindle shaped structure. In B (fig. 6) is reproduced a drawing of the $53 \mathrm{~d}$ section of this series. In this section the cells of the head process present a distinctly radial arrangement about a mall centrally placed lumen, the structure constituting a chordal canal, 
not as yet distinctly separated from the bordering mesoderm, which extends as a well developed layer to the borders of the embryonic area. This section-as other sections-was drawn by aid of camera lucida at a magnification of 600 ; reduced in reproduction. This magnification was sufficient to enable determining clearly the relations of the structures sketched; the figure may thus serve to show that the chordal canal is at this stage distinctly separable from both ectoderm and entoderm. A distinct chordal canal is traced through 24 sections of this series. In certain of these sections the lumen appears double, again fusing to a single lumen; a phenomenon previously observed. In the 76th section, the distinct limiting membrane separating chordal canal and ectoderm disappears and the wall of the chordal canal which is directed toward the ectoderm fuses with the ectoderm the lumen of the canal, however, is still evident. The region of the well developed primitive node found in this series is shown in $\mathrm{C}$ (fig. 6), reproducing a drawing of the 84th section. In this primitive node region the caudal end of the chordal canal and the mesoderm are fused with the ectoderm, as this drawing clearly portrays; the mesoderm extending as a massive layer to the limits of the embryonic area. In this series it is impossible to trace the lumen of the chordal canal to the surface of the ectoderm; neither is there observed a distinct infolding of the ectoderm of this region. A slight protrusion of cells in the center of the node region is noted, though this is not as pronounced as that figured by Carius for the rabbit. In D (fig. 6 ) is reproduced a drawing of the 106th section of this series, inserted to show a typical section of the primitive streak and groove region as presented in this series. The relations of the mesoderm to the ectoderm of the primitive streak region is here clearly shown, the direction of the long axis of the nuclei of ectodermal cells of this region evidencing a proliferation and migration of ectodermal cells to the mesoderm.

The chordal canal is a structure well recognized in embryologic literature and has been described for a number of mammals and other amniotes. Almost immediately after its anlage, its ventral surface comes into very intimate relation with the under- 
lying entoderm, though in all of the series of section of embryonic shields of the guinea pig, showing chordal canal, the entoderm extends as an uninterrupted layer of flattened cells along the ventral-entodermal-surface of the chordal canal and head process. Soon after the anlage of the chordal canal, there may be noted in its caudal portion a dehiscence along its ventral wall, including underlying entoderm, so that the chordal canal assumes the form of an inverted trough, opening into the subentodermal space. The caudal end of the chordal canal, in certain of the mammalian embryonic shields carefully studied, extends to the dorsal surface of the ectoderm in the region of the primitive node, its lumen thus extending to the amniotic cavity, forming the neurenteric canal. The metamorphosis of the head process into chordal canal and the opening of this into the entoderm is described as follows by $O$. Hertwig:

Der Kopffortsatz bckommt in seinem Innern eine Höhlung, die meist als Chordakanal, zuweilen auch als Canalis neurentericus bezeichnet wird; seine untere Wand, nach dem sie mit dem innern Keimblatt eine Verschmelzung eingegangen ist, reisst längs dieser Naht ein; dadurch wird jetzt der Chordakanal seiner Länge nach in den unter dem innern Keimblatt gelegen Raum eröffnet.

As is also noted by $O$. Hertwig, slight variations in the detail of formation of the chordal canal in mammalia has been observed, to the extent, that two main types are recognized. In the one type the chordal canal is relatively short, opening almost immediately after its anlage into the entoderm as observed in the rabbit, sheep and pig. In the other type the chordal canal forms a much more definite structure, extending for a relatively long distance cephalad, as in the guinea pig and the bat (Vespertilio murinus) and according to the recent account of Grosser. in the human embryo. Particularly in the guinea pig may there be observed a relatively long and well developed chordal canal, known to literature through the studies of Lieberkühn, Keibel and Graf Spee.

In figure 7, there is presented a drawing of the 74th section of a series of 150 sections, each of $7 \mu$ thickness, of the embryonic area of a guinea pig removed from the uterus 13 days and 12 
hours after insemination, and cut in the sagittal plane. This series was very fortunately cut, the line of sectioning being almost exactly parallel to the mid axis of the embryonic shield. The figure reproduced is drawn from a single section. The caudal end of the section reproduced is readily recognized by means of the prominent allantoic anlage and which in the figure is directed toward the top of the page. For about the upper half of the length of the figure, the section passes through the primitive groove. The region of the primitive node with shallow primitive pit is indicated by figure legend, pr.n. From the caudal end of the embryonic area to the region of the primitive node the ectoderm shows no definite ventral boundary, but is continuous with the mesoderm of the primitive streak region. Cephalad to the primitive node region the ectoderm is bounded on its under surface by a distinct limiting membrane. Beneath the ectoderm of this region, and in close relation to it, there may be observed a long chordal canal, cut nearly through its whole length so as to include its lumen. The extent of the chordal canal is indicated by two crosses placed in the figure just beneath the entoderm. Beneath the chordal canal, the entoderm may in places be observed as a thin cuticular layer, with nuclei here and there evident. In this preparation, the chordal canal opens into the entoderm for a short distance, as is clearly seen in the figure. The chordal canal, in this preparation, does not reach the cephalic limit of the head process, this extending for a short distance cephalad, beyond the region in which a distinct chordal canal lumen can be determined. The anterior limit of the head process is not clearly defined in the series from which figure 7 was drawn. In another embryonic shield of about the same stages of development and taken from the same uterus also cut in the sagittal plane, but not in such favorable direction, the head process can be traced fairly distinctly over a continuous layer of entoderm, to near the region of the future pharyngeal membrane, though the head process cells appear as firmly fused to the entoderm. Figure 8, which is drawn from the same series from which figure 7 was taken, reproduces a portion of the 76 th section and was drawn 
G. CARL HUBER
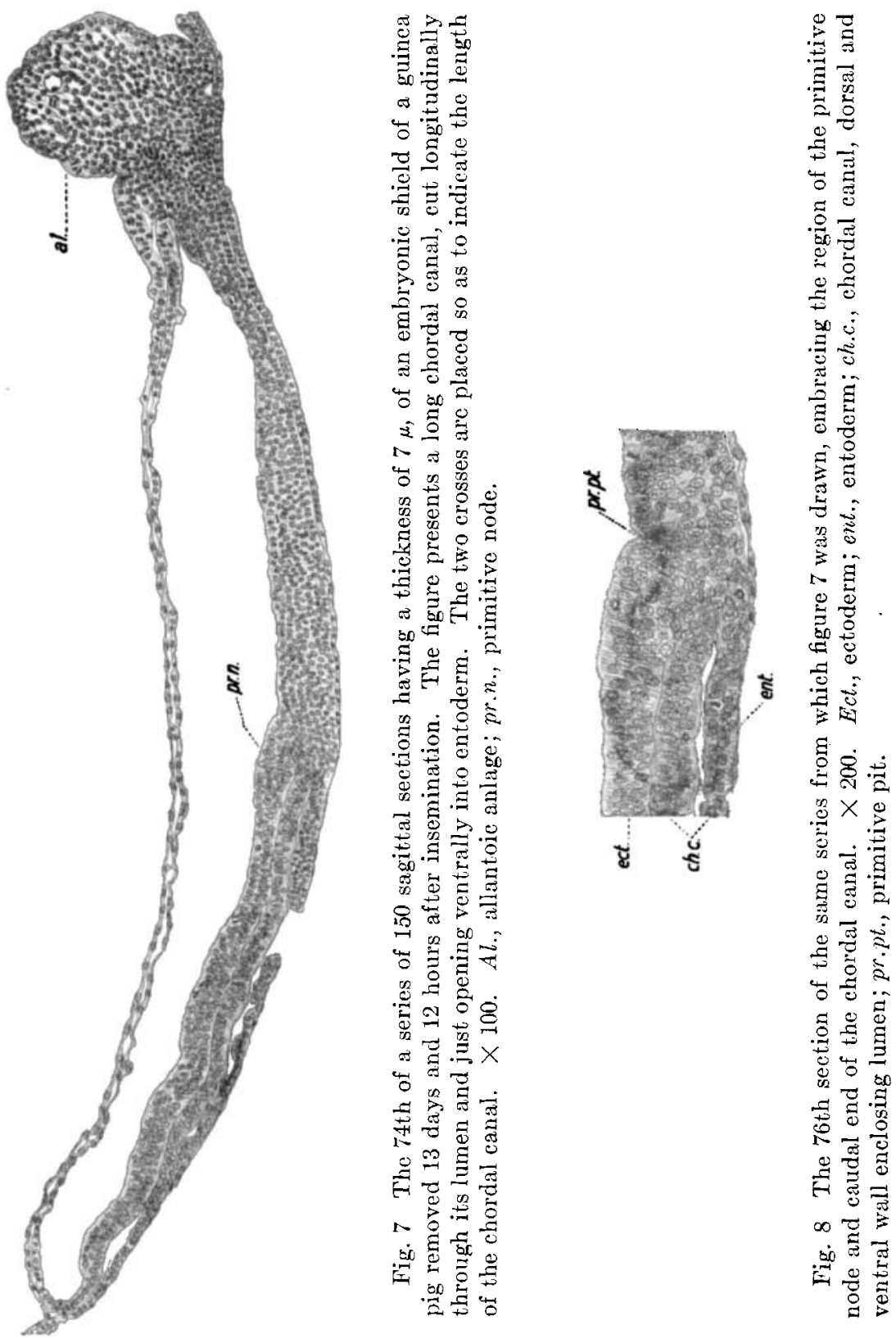
at a higher magnification and embraces the primitive node region and the caudal end of the chordal canal. This section, for this region, passes more nearly through the mid plane of the embryonic shield than does section 74 , the basis of figure 7 . $A$ distinct primitive pit, pr.pt., is to be noticed in the primitive node region. The relation of the caudal end of the chordal canal to the ectoderm of the primitive node region is to be noted; the direction of the long axis of the nuclei of the ectodermal cells evidencing a growth zone for the chordal canal in the ectoderm of this region. The distinct separation of the ectoderm from the definitive chordal canal is to be observed. The relation of the entoderm to the caudal end of the chordal canal and the ectoderm-mesoderm mass of the primitive node region, is clearly shown in this figure; the entoderm extending as an uninterrupted continuous layer, consisting of flattened cells, beneath nearly the whole extent of the region figured. An extension of the lumen of the chordal canal to the surface of the ectoderm is not observed.

In none of my series, whether sectioned in the cross or the sagittal plane have I been able to determine a patent nuerenteric canal. This agrees with the observations of Lieberkühn, who states, referring to the chordal canal:

"Auch ist es mir nie gelungen eine ausmündung desselben an der Oberfläche des Ectoblast wahrzunehmen,"

Graf Spee in discussing this point describes a neurenteric cord-'Neurenterischen Strang'-with cell nuclei radially arranged, but having no lumen, and extending obliquely from ectoderm to entoderm, however, not distinctly separated from the cells of the primitive node region. This I have observed in a number of my series, cut in cross sections.

Grosser's account of a human embryo with chordal canal, is of interest in this connection. In the human embryo in question, with probable age of 18 days, the embryonic shield measured $670 \mu$, with well developed chordal canal, having a length of $190 \mu$. The chordal canal was found to open into the entoderm with two openings and on to the ectoderm by means of one small opening. As has been known for some time, the human embryonic shield of the pertinent stage, presents a patent neurenteric canal, well 
known through Graf Spee's description and figures of embryo G.le., and other more recently described embryos, including this of Grosser. So far as I am able to judge from a study of figures, the chordal canal of the human embryo described by Grosser presents many points of similarity to that found in the embryonic shield of the guinea pig presented in figure 7 , the primitive streak region, however, being distinctly longer in the guinea pig. Grosser has called attention to the resemblance of the chordal canal in human and guinea pig embryos, stating:

"Am nächsten kommen noch die Bilder, die Lieberkühn vom Mecrschweinchen giebt."

Figure 7, in its main features is comparablewith the well known figures given by Van Beneden, giving mid sagittal sections of embryonic shields of Vespertilio murinus. In the embryonic shield of this bat there is present a patent and very distinct neurenteric canal. Van Beneden described two kinds of openings of the chordal canal into the entoderm. 1. An anterior opening consisting of a broad transverse slit. 2. Several smaller openings which soon fuse to form a single longitudinally directed slit. I am in accord with Keibel, when he states, referring to the two kinds of openings of the chordal canal into entoderm:

"Bei Kaninchen erscheint mir dieselbe durchaus nicht zutreffend, und wie schon gesagt, finde ich sie auch für Meerschweinchen nicht bestätigt."

Lieberkühn was the first to call attention to the fact that the chordal canal does not open ventrally, primarily, by means of a single longitudinally directed slit, but usually by means of a series of smaller openings. This is clearly seen in his figure 30 of plate 20 , giving a ventral surface view of an embryonic shield, also his figures 25 to 29 of the same plate. This fact is also clearly shown in the series of ten drawings grouped under figure 9. These drawings are from representative sections of an embryonic shield of a guinea pig removed from the uterus 13 days and 12 hours after insemination, and taken from the same uterus from which the embryonic shield, a section of which was reproduced in figure 7 was taken, though that shield is of slightly younger stage of development. The series of sections of the 

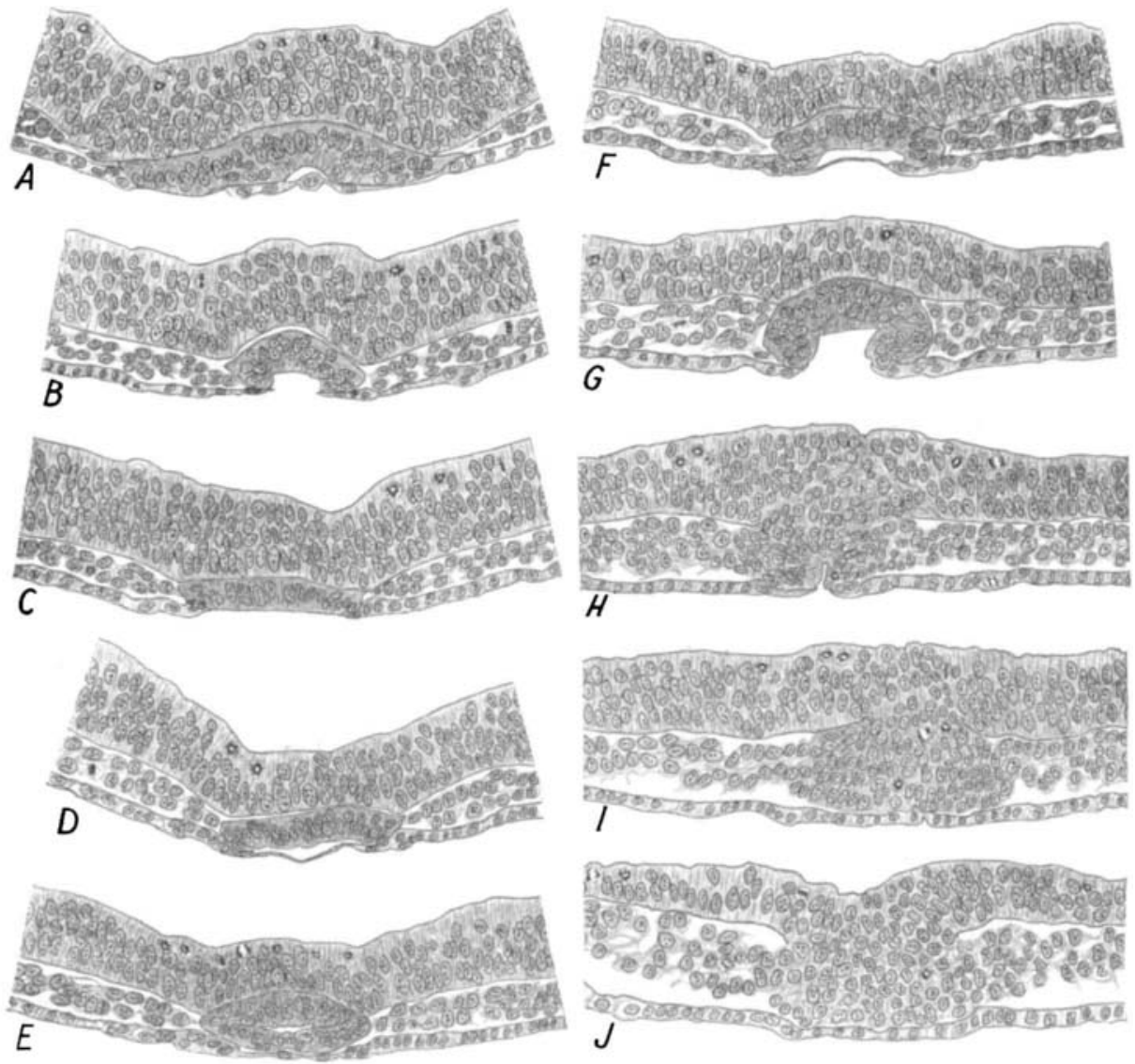

Fig. 9 A to $J$. Drawings of representative cross section of an ambryonic shield of the guinea pig, removed 13 days and 1 hour after insemination. The series embraces 188 sections of $7 \mu$ thickness. $\times 200$. A, 33rd section, through chordal plate with entoderm extending beneath; $B$, 43rd section, with arched chordal plate, entoderm extending under borders of chordal plate; C, 53 rd section, flattened chordal plate incorporated in entoderm; D, 66th section, with flattcned chordal plate with entoderm extending beneath; $F, 79$ th section, arched chordal plate with entoderm extending beneath; G, 107th section, arched chordal plate, entoderm extending under the borders of chordal plate; H, 114th section, chordal canal reaches into ectoderm; I, 120th section, primitive node region; $J$, 155th section, primitive streak region. 
embryonic shield from which figure 9 is drawn, numbers 188 cross sections having a thickness of $7 \mu$. Each of the several drawings of this figure includes the axial portion of the embryonic shield as seen in cross section, with the ectoderm of the medullary plate, the primitive node and the primitive streak directed upward and with mesoderm and entoderm in normal relations. The chordal canal or metamorphosed chordal canal structures are to be found in the middle and under side of each drawing, either as a closed chordal canal or showing various degrees of ventral dehiscence and socalled incorporation into the entoderm. A (fig. 9) is of a drawing of the 33d section, counting from the cephalad border of the embryonic shield. This section falls to the region slightly caudal to the region of the future pharyngeal membrane, a region in which it is believed a chordal canal with patent lumen does not develop, instead, the cells of the head process differentiate to form a chordal plate composed of short columnar cells, as indicated in the drawing. It will be observed that the entoderm extends beneath this chordal plate, in the drawing from right to left, for nearly the entire extent of the chordal plate. $B$ of this series reproduces a drawing of the $43 \mathrm{~d}$ section. In this region the chordal canal has opened ventrally, presenting in cross section the form of an inverted trough. It is further to be noted that the dehiscence extends through the entoderm, but that the edges of the entoderm extend beneath the borders of the arched chordal plate. $\mathrm{C}$ of this series is a drawing of the $53 \mathrm{~d}$ section. The borders of the chordal plate are in this region spread out so as to bring the plate into a plane, seemingly incorporated between the edges of the cleft entoderm. However, by reason of the staining reaction of the protoplasm of the cells of the chordal plate and their short columnar shape, they are readily differentiated from the entodermal cells. D, of this series is of a drawing of the 66 th section. In this region the chordal canal through ventral dehiscence and spreading has assumed the form of a plate, however the splitting did not involve the entoderm, this extending as a cuticular layer beneath the plate of chordal cells. E, of this series is of a drawing of the 75th section. In this region 
there may be observed a very distinct chordal canal, with slit like lumen, the entoderm extending as an uninterrupted layer of flattened cells beneath the chordal canal. In F, of this series there is reproduced a drawing of the 79th section, and is of a region in which the entoderm extends as a cuticular layer beneath an arched chordal plate. $\mathrm{G}$, of the series, is of a drawing of the 107th section. The region from which this section was taken approaches the primitive node region. The ventrally opened chordal canal presents in cross section the form of an arch the lips of the split entoderm extending under the borders of the arched chordal plate. Throughout this portion of this series of drawings, $\mathrm{A}$ to $\mathrm{G}$, the chordal canal or plate is distinctly separated from the ectoderm, this presenting a definite limiting membrane on its under or ventral side. In $\mathrm{H}$, of this series, reproducing a drawing of the 114th section, the chordal canal reaches into the ectoderm of the primitive node region and is no longer distinctly separated from the ectoderm, although the fusion with the ectoderm is not as yet as complete as shown in the following drawing. Ventrally the chordal canal opens into the entoderm through a narrow slit. I, of this series reproduces a drawing of the 120th section, which passes through the primitive node region. In this region the caudal extension of the chordal canal is distinctly fused with the ectoderm, the direction of the long axis of the nuclei and the active mitosis indicating an ectodermal growth zone for the chordal canal. J (fig. 9) reproduces a drawing of the 155th section, which passes through the anterior portion of the primitive streak and groove, and is added to show the active participation of the ectoderm of the primitive streak region in the formation of mesoderm. Throughout the primitive node the entoderm extends as an uninterrupted layer of cells.

This series of drawings may serve to illustrate how difficult it would be to portray adequately by means of a single illustration the dehiscence of the ventral wall of the chordal canal and its incorporation in the entoderm of the axial portion of the embryonic shield. A definite incorporation of the chordal plate into the entoderm, it would appear to me, does not obtain, and 
as concerns the guinea pig, there is at hand no evidence that the entoderm in any way contributes to the histogenesis of the chordal canal or chordal plate. In corroboration of this conclusion two further series of drawings are here added: they are of cross sections of slightly older stages than that discussed under figure 9.

In figure 10 , drawings $\mathrm{A}$ to $\mathrm{F}$, there are presented a series of six drawings of cross sections of an embryonic shield of the guinea pig removed from the utersu 14 days and 11 hours after insemination. This series included 188 cross sections of $7 \mu$ thickness. Measured as to age, reckoned from time of insemination to time of killing, this embryonic shield is nearly a day older than that discussed under figure 9. In actuality it presents only a slight advance in development; both as to general development and specifically as concerns chordal structures and their relations. Drawing A (fig. 10) is of the 30 th section counting from the cephalic border of the embryonic shield, and is from the region slightly caudal to the future pharyngeal membranes. A chordal plate is here observed with the entoderm extending as an uninterrupted layer ventral to it. $B$, of this series is of a drawing of the 44th section. Here also the entoderm extends ventral to the chordal plate. $\mathrm{C}$, of this series is of a drawing of the 57th section. In this region there is observed a slit in the entodermal layer, the edges of the split entoderm extending under the borders of the chordal plate. D, of this series reproduces a drawing of the 86th section. In this region the chordal plate is relatively wide, and as seen in cross section, of the form of a broad arch, with the edges of the separated entoderm extending under the borders of the chordal plate. E, of this series reproduces a drawing of the 107 th section, which approaches the region of the primitive node. The ventrally open chordal canal presents in cross section the form of an arch, beneath which extends the entoderm as a thin but continuous layer. In the several drawings of this series, $A$ to $\mathrm{E}$, thus far considered, the ectoderm is separated from the chordal plate by a distinct, basal limiting membrane. $F$, of this series is of a drawing of the 119th section, which passes through the primitive node region, in 
which region the caudal end of the chordal canal is continuous with the ectoderm with total disappearance of the basal limiting membrane. The active mitosis of the ectoderm and deeper cells indicate a region of growth activity. Ventrally the mesodern is in continuity with the cells of the primitive node. The entoderm passes uninterruptedly ventral to this area. In no por-
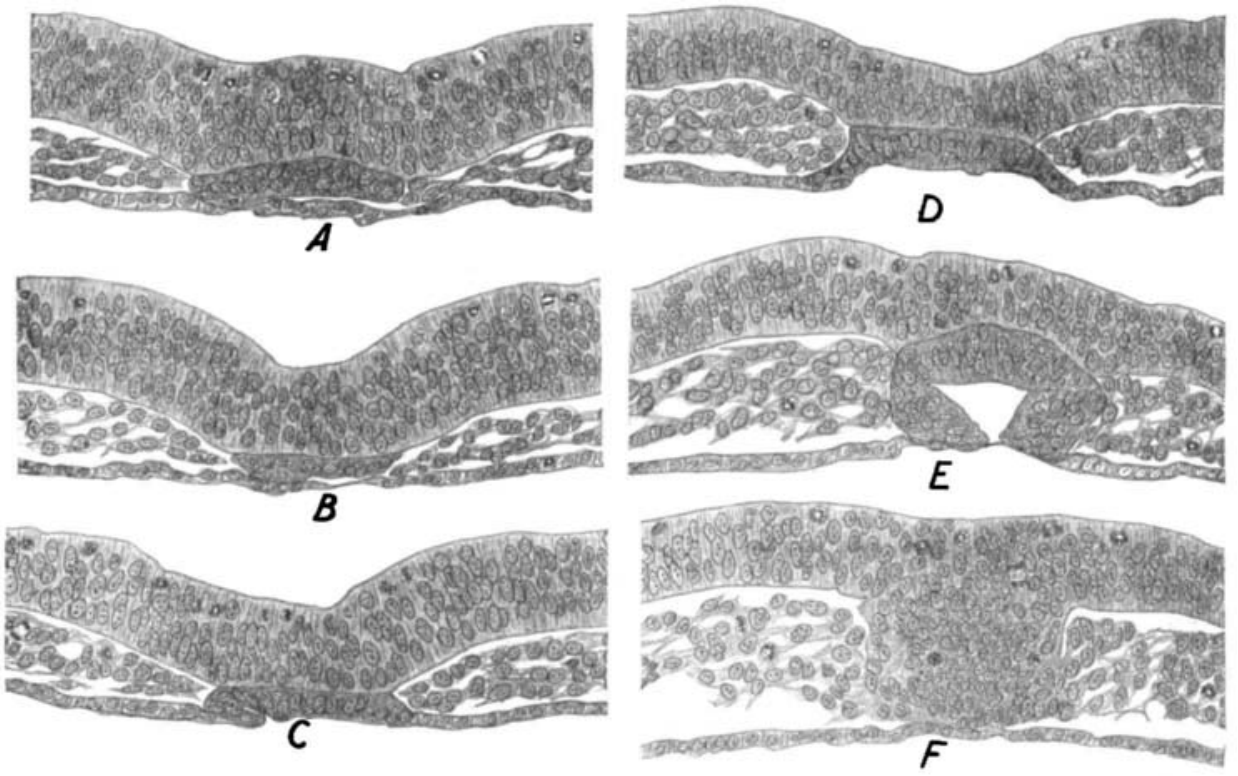

Fig. 10 A to F. Drawings 0 representative cross sections of embryonic shield of the guinea pig, removed 14 days and 11 hours after insemination. The series embraces 188 sections shaving $7 \mu$ thickness, and shows relations of the chordal plate. $\times 200$. A, 30th section, with flattened chordal plate with entoderm extending beneath; B. 44th section, with flattened chordal plate with entoderm extending beneath; C, 57th section, chordal plate incorporated in entoderm; D, 86th section, wide arched chordal plate incorporated in entoderm; E, 107th section distinctly arched chordal plate with entoderm extending beneath; F, 119 th section, primitive node region.

tion of this series, from region of the primitive node to cephalic end of head process was there observed a closed chordal canal, though in several regions the entoderm extends beneath the chordal plate, which results from dehiscence of the ventral wall of the chordal canal. In the regions in which the entoderm presents a cleft under the chordal plate, the edges of the cleft entoderm extend slightly under the borders of the chordal plate. 
In figure $11, A$ to $\mathrm{F}$, are reproduced a series of six drawings of respective cross sections of an embryonic shield of a guinea pig removed from the uterus 14 days and 7 hours after insemination. This embryonic shield was cut in cross sections having $5 \mu$ thickness; 327 sections fall to the embryonic shield. As measured by age this embryonic shield is slightly younger than that discussed under figure 10; as judged by stage of development, it is slightly older, as indicated in general by the presence of a well developed medullary groove in the cephalic portion of the embryonic shield. In A (fig. 11) is reproduced a drawing of the 42nd section, counting from the front part of the embryonic shield. This section passes just caudal to the forming foregut, so that the entoderm is cut slightly tangential, this accounting for its apparent thickness as seen in the figure. In this region the chordal plate is relatively wide, with the entoderm, left side of the figure, extending beneath the chordal plate. In B, of this series is reproduced a drawing of the 67 th section. In this region the chordal plate is relatively narrow, with the edges of the cleft entoderm extending distinctly under the borders of the chordal plate. In $\mathrm{C}$, of this series is reproduced a drawing of the 123rd section and gives a conventional figure of a flat chordal plate apparently incorporated into the entoderm, though on closer study it may be observed that the edges of the cleft entoderm extend slightly under the borders of the chordal plate. D, of this series is of a drawing of the $223 \mathrm{~d}$ section. In this region the chordal plate is again relatively wide, appearing in cross sections slightly arched, and especially on the left side, definitely incorporated in the entoderm; the edge of the entoderm extending under the border of the chordal plate on the right side. In $\mathrm{E}$, of this series there is reproduced a drawing of the 234th section; this approaching the region of the primitive node. In this section, as may be observed from the figure, the chordal plate is not completely separated from the ectoderm, but in the middle of the chordal plate, it is continuous with the ectoderm; the rather distinct radial grouping of the nuclei in the region of fusion of the chordal plate and ectoderm indicating the region of the neurenteric cord as described by Graf Spee. In F, of this series there 
is reproduced a drawing of the 238th section, which passes just cephalad of the anterior border of the primitive node, and presents the caudal end of the definitive chordal canal and its extension into and fusion with the ectoderm of the primitive node
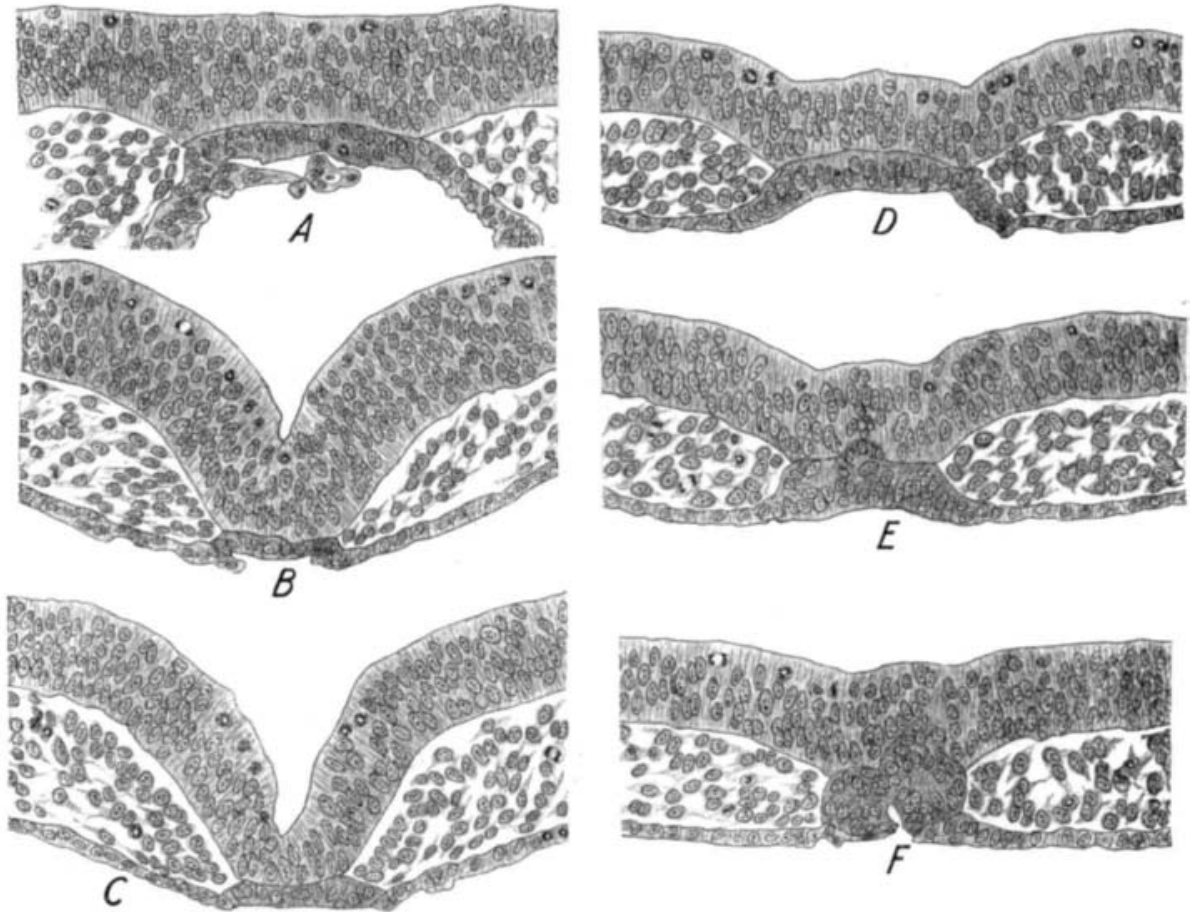

Fig. 11 A to F. Drawings of representative cross sections of an embryonic shield of the guinea pig removed 14 days and 7 hours after insemination. The entire series embraces 327 sections having $5 \mu$ thickness; neural groove in cephalic portion of embryonic shield; as yet no somites; final stage of chordal plate. $\times 200$. A, 42nd section, just caudal to foregut, chordal plate with entoderm extending beneath; $\mathrm{B}, 67$ th section, flattened chordal plate with entoderm extending under the borders of the chordal plate; $\mathrm{C}, 123 \mathrm{~d}$ section, flattened chordal plate beginning to fuse with the ectoderm; $D, 223 \mathrm{~d}$ section, relatively wide and slightly arched chordal plate incorporated into the entoderm; E, 234th section, approaches primitive node region, chordal plate beginning to fuse with ectoderm; F, 238th section, just cephalad to border of primitive node.

region. The narrow ventral cleft extends through the entoderm, the edges of the cleft entoderm passing beneath the borders of the ventrally open chordal canal. Throughout this series the chordal plate is only in part incorporated in the entoderm. In figure 
12 , is presented a drawing of a mid sagittal section of an embryonic shield of practically the same stage of development as that discussed under figure 11. This series is of an embryonic shield of a guinea pig removed from the uterus 14 days and 12 hours after insemination, and includes 156 sections having $7 \mu$ thickness. The figure reproduces a drawing of the 79th section, and is drawn from a single section, the line of sectioning in this series being almost exactly parallel to the mid axis. The caudal end of the section is directed toward the top of the page, as evidenced by the prominent allantoic anlage. A study of the series reveals that the stage of development is that just prior to the formation of the first somite, this being indicated but not completely formed. The primitive streak region extends for a little more than a third of the length of the embryonic shield. The first indication of the pericardial space is to be noted. The chordal plate of this shield extends from the region of the primitive node, pr.n., to approximately the region of the future pharyngeal membrane, and is in close relation to the ectoderm, being separated from it by the distinct basal limiting membrane of the ectoderm. Here and there entodermal cells are to be observed beneath the chordal plate. The chordal canal is still evident for a short distance at the caudal end of the chordal plate, which becomes continuous with the ectoderm of the primitive node region. At this stage the ectoderm and mesoderm are still continuous in the primitive streak region, the entoderm extending beneath this region as an uninterrupted layer. In order to reproduce in one section, reduced to page length, the entire embryonic shield in a mid sagittal section, the reduction necessary obviates a clear presentation of details. It is hoped the figure is sufficiently clear to enable orientation. It may also be stated that cross sections give clearer pictures of the relations of the chordal plate at this stage than do sagittal sections. These two series, figures 11 and 12, it may be stated, represent approximately the final stage in chordal plate morphogenesis and its incorporation into the entoderm. This stage is followed by one in which the chordal plate again separates from the entoderm and differentiates to form the definitive chordal dorsalis. 


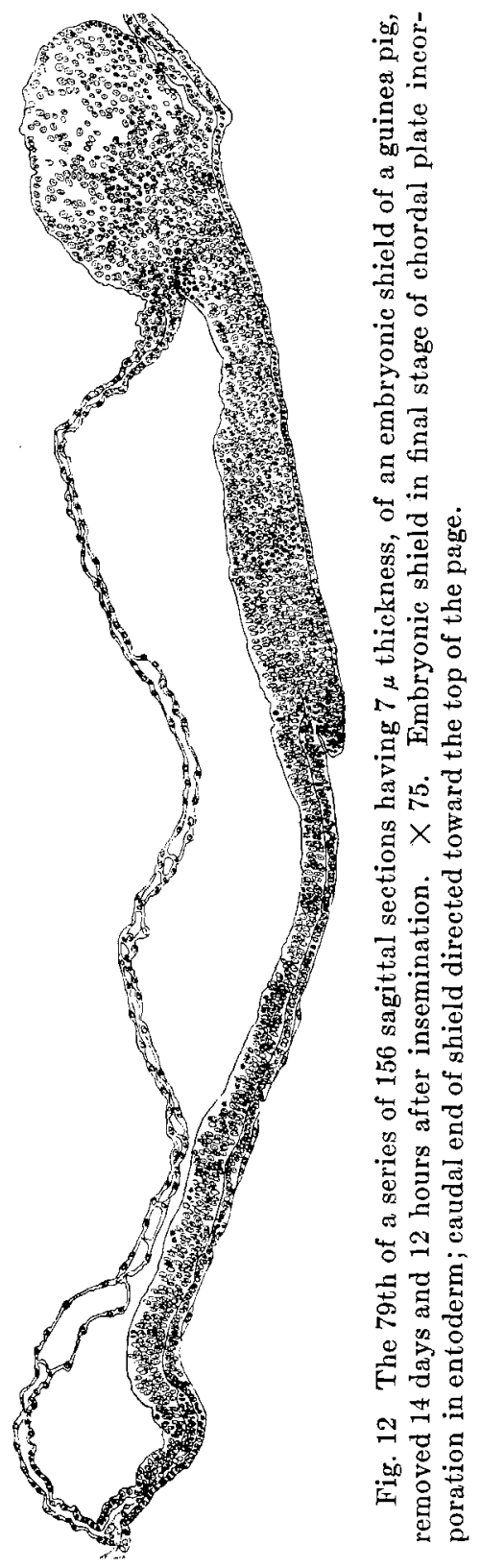


O. Hertwig's endeavor to find support for his 'Celometheorie' in mammalian embryonic dises with ventrally open chordal canal, it would seem to me, is not sustained. Hertwig finds support for his contention in the accounts and figures of Heape -mole, and Van Beneden-rabbit. In his discussion of these figures (figs. 618 and 619) he states:

"Links und rechts geht das Chordaepithel Kontinuierlich in das parietale Blatt des Mesoblasts über, das aus mehr abgeblatteten Zellen besteht."

As my own figures may serve to show (figs. 8, 9, and 10), the mesoderm is not directly continuous with the borders of the chordal plate, from the region just cephalad of the primitive node to its anterior limits.

The separation of the chordal plate from the entoderm has been carefully studied by a number of investigators; first by Lieberkühn, in the guinea pig, later by Keibel, in the guinea pig and rabbit. Keibel formulates his conclusions as follows:

Die Chorda kann sich aus dem Verbande des Entoblasts sowohl durch einfache Unterwachsung, als durch directe Einfaltungsprocesse auschalten. In ersteren Falle erhalten wir cine platte Chorda, wie sie Z. B. aus dem Köllikerschen Handbuch bokannt genug ist; im zweiten hat die Chorda alsbald eine Gestalt, welche ihrere definitiven glcich ist oder ihr doch nahe kommt. In den Fällen, in welchen die Chorda zunächst cinfach aus dem Entoderm ausgeschaltet wird, erfolgt nachträglich eine Umordnung der Chordazellen, welche einem Einfaltungsvorgang gleich zu setzen ist. In beiden Fällen kann nachträglich noch ein Canal im Inneren der Chorda auftreten, welchen ich als "secundären Chorda canal" bezeichnen will.

These two methods of chordal plate separation, it seems to me, are exemplified in the figures presented in figure 13. The series forming the basis for this figure are of an embryonic shield removed from the uterus 14 days, 11 hours after insemination, and are from the same uterus from which the embryonic shield described under figure 10, was taken. The series includes 340 sections of $7 \mu$ thickness. There are present five pairs of somites with a sixth pair forming. In $A$ (fig. 13) is reproduced a drawing of the 170th section. The line of sectioning is not quite at right angles to the mid axis, as evidenced by the difference in 

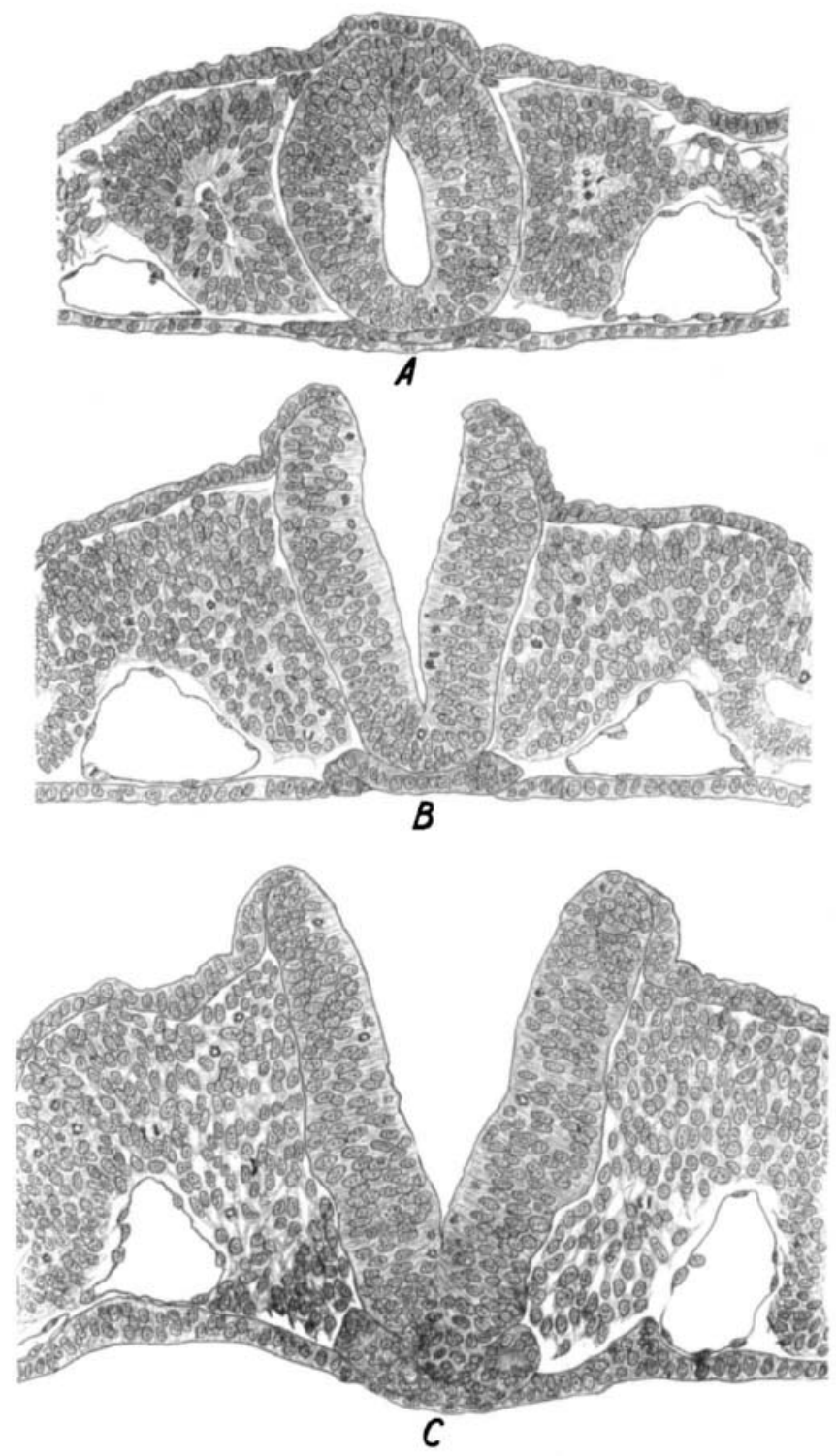

Fig. 13 A to C. Drawings of cross sections of an embryonic shield of the guinea pig removed 14 days and 11 hours after insemination. The entire series embraces 342 sections having $7 \mu$ thickness. This embryonic shield possesses five pairs of somites with a sixth pair forming and presents early stages in separation of chordal plate from the entoderm. $\times 200$. A, 170th section, flattened chordal plate found between closed neural tube and entoderm; B, 252nd section, to the left border of ehordal plate folded ventrally; $\mathrm{C}, 300 \mathrm{th}$ section, primitive streak region, chorda dorsalis in the act of separating from the primitive streak region. 
structure presented in the drawing by the two opposed somites, the one cut through its middle, the other not. The chordal structure appears as a flattened plate, situated between the closed neural tube and the continuous entoderm. It would appear that in this region the borders of the split entoderm had grown toward the midline and fused. In $\mathrm{B}$, of this series is reproduced a drawing of the $252 \mathrm{nd}$ section. This section approaches the region of the primitive node. There is present in this region an open neural groove. The chordal plate was fixed in the act of being rolled under, seen clearly only on the left side of the figure. These two figures, it would appear to me, evidence the two methods of separation of the chordal plate, from the entoderm-undergrowth of entoderm ventral to the chordal plate and infolding of the borders of the chordal plate. Especial attention has been given to the manner of the caudal extension of the chordal structures, caudal to the primitive node region, and, to the relative and absolute shortening of the primitive streak; by Lieberkühn in the guinea pig, Bonnet in the sheep and Keibel in the guinea pig and the pig. Exact measurements are presented which show that the primitive streak becomes relatively and absolutely shorter as development progresses. Though I present here no exact measurements, my own observations corroborate this, as may readily be ascertained on study of figures 4,5 , and 7 , and on comparing these with figure 12, all of drawings of mid sagittal sections of progressive stages of development. The morphogenesis of the chorda dorsalis in the region caudal to the primitive node, namely in the primitive streak region, it would seem to me is well shown in C (fig. 13) the 300th section of this series. As is well known, in the axial portion of the primitive streak the ectoderm presents no basal limiting membrane. From the time of mesoderm anlage, ectoderm and mesoderm are in this region inseparably fused; the ectoderm here constituting the primary source of the mesoderm. With the stage when the chordal plate begins to separate from the entoderm, the ventral cells of the ectoderm-mesoderm mass in the primitive streak region begins to separate from the lateral mesoderm and from the overlying ectoderm proper, the latter differen- 
tiating to form the neural plates, the sides of the neural groove and later neural canal, a definite basal limiting membrane separating the ectoderm of the neural plate and canal from the chordal structures developing. This it seems to me is in process of attainment in the region of the section sketched in C (fig. 13) the section passing through the caudal portion of the primitive node, no longer clearly defined. As may be observed on study of this section the chorda dorsalis is only in part differentiated, dorsally it is still in direct continuity with the floor of the neural groove. So far as my observations go, no definite chordal canal is to be observed in the primitive streak region and the term head process seems to be inappropriately applied to this structure in this region. From the region of the primitive node caudalward, the entoderm of the axial portion of this region at no time presents a ventral cleft, but at all stages in development passes as an uninterrupted layer, in close relation to the overlying mesoderm, but in no sense fused with it in the way that the ectoderm and mesoderm are fused in the primitive streak region. So far as I have been able to determine entoderm of this region takes no part in the morphogenesis of the chorda dorsalis and the latter can not be said at any time to be incorporated in the entoderm of this region. The two drawings reproduced in figure 14, are from a slightly older stage than that shown in figure 13. They are made from cross sections of an embryonic shield removed 14 days 12 hours after insemination. The series includes 300 sections of $10 \mu$ thickness. A (fig. 14) reproduces a drawing of the 132nd section. Ventral to the closed neural canal and between this and the continuous layer of entoderm, there may be observed a chordal plate in process of transformation to definite chorda dorsalis; the borders of the chordal plate appear in the act of turning in to form a chordal structure. B, of this series, reproduces a drawing of the 236th section, taken from the region of the anterior part of the primitive streak in which the chorda dorsalis is completely separated from both the ectoderm and entoderm, a completion of the process shown in its inception in $\mathrm{C}$ (fig. 13). The mode of the separation of the chorda dorsalis as here described is not quite the same as that given by 
Keibel. From his studies on the embryonic shield of the pig, he is led to the following conclusion, given here in his own words:

Der Kopffortsatz muss auf Kosten des Primitivstreifens gewachsen sein. Dies Wachsthum müssten wir uns so vorstellen, dass immer der vorderste Theile des Primitivstreifens sich in dem Kopffortsatz umbildst, und damit dem entsprechend das vordere Ende des Primitivstreifens zurückweicht.
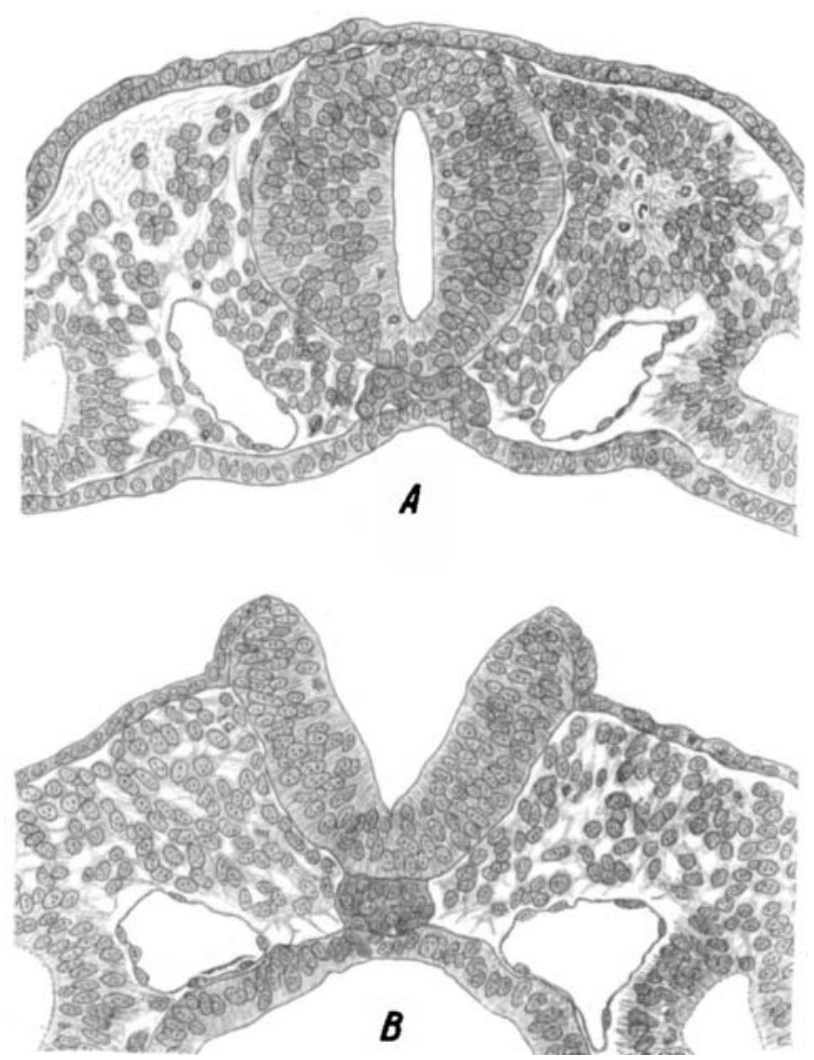

Fig. $14 A$ and $B$. Drawings of cross sections of an embryonic shield of the guinea pig removed 14 days, 12 hours after insemination. The entire series embraces 300 sections of $10, u$ thickness. Chordal plate nearly separated from entoderm, to form the chordat dorsalis. $\times 200$. A, 132nd section, arehed chordal plate, in the act of folding in to form chorda dorsalis, situated between neural tube and closed entoderm; B, 236th section, chorda dorsalis separated fromectoderm of neural plates and the entoderm in the primitive streak region. 
It has here been contended that the head process is a derivative of the primitive node and grows cephalad between ectoderm and entoderm and from its anlage is separated from the ectoderm by means of a distinct basal limiting membrane. Keibel's conclusion seems to me applicable only to that part of the chorda which develops caudal to the primitive node, in particular to the primitive streak region, the process resulting in an absolute shortening of the primitive streak and in the formation of a chorda dorsalis.

The development and relations of the anterior end of the chorda dorsalis have been the subject of special considerations in several investigations. In the guinea pig, as has previously been stated, the anterior end of the head process can be traced to the region of the future primary pharyngeal membrane. This is clearly shown in figure 5, and this question was discussed in connection with this figure. A definite chordal canal, so far as my material enables me to determine, does not develop to the anterior limits of the head process. The cells of the cephalic end of the head process, with nuclei arranged in one or two strata, come in very close relation with the underlying entoderm, so that at times it becomes difficult or quite impossible to differentiate clearly between cells of the head process and the underlying entoderm. I am led to conclude that the entoderm of this region at no time develops a distinct cleft, admitting of incorporation of head process in the entoderm. These observations are in the main in accord with those of Keibel, with reference to the cephalic end of the chorda anlage; his words read as follows:

Am schwierigsten liegen die Verhältnisse jedenfalls am Vorderen Ende des Embryos. Dort ist das Entoderm schon vor der Einschaltung der Chorda verdickt und, nachdem die Einschaltung geschehen ist, lässt sich beim besten Willen keine Grenze mehr zwischen den eingeschalteten Zellen und dem Entoblast erkennen.

Notwithstanding, Keibel is of the opinion, that the entire chorda dorsalis is developed from cell material derived from the head process. On further development, the cells of the head process, for a time intimately blended with the underlying ento- 
derm, separate again from the entoderm; the two structures are then readily differentiated. Bonnet in his contributions to the embryology of the sheep contends that the anterior end of the chorda dorsalis is derived directly from the entoderm, the 'chordaentoblast.' This idea is developed and modified in his studies on the embryology of the dog. In this contribution he speaks of an 'Ergänzungsplatte des Urdarmstrangs' out of which develops the mesoderm of the anterior part of the head, the chorda of the anterior part of the head and a 'prämandibulares Darmrudiment.' In the guinea pig, as also previously determined by Keibel, such an 'Ergänzungsplatte' can not be differentiated, and I question its existence in other mammalia. In Grosser's preparation of a human embryo with chordal canal it was also impossible to determine definitely the anlage of the cranial end of the head process, his own words, omitting references to plates, read as follows:

"Ganz am cranialen Ende des Kopffortzatzes findet sich eine Region, in der die Abgabe von Material aus dem Entoderm an das Mesoderm nich auszuschliessen ist (Protochordal-oder Ergänzungsplatte); doch ist die Konsservierung gerade dieser Stelle wenigen günstig."

It has been the aim in this communication to present in successive stages, illustrated by figures drawn of sagittal and cross sections, the anlage and morphogenesis of the chorda dorsalis in the guinea pig, a form in which the successive stages of chordal development are relatively easily determined, by reason of size of structure and definition of stages, if suitable material is at hand. It is recognized that a comprehensive discussion of this fundamental problem, even so far as concerns only the amniotes, requires a comparison of results here obtained with observations made on other mammalian forms as also avian and reptilian forms. It is hoped that further study will admit of this. The observations pertaining to the guinea pig, as here briefly recorded, seem to me to warrant the following summary and conclusions:- 


\section{SUMMARY AND CONCLUSIONS}

1. In the guinea pig, the head process has its anlage in the cranial border of the primitive node, an area of ectodermal proliferation, forming the cranial end of the primitive streak; by accretion of cells and proliferation of its own cells, the head process grows cephalad in the axial portion of the embryonic shield, primarily independent of the later wings of the mesoderm, to reach approximately the seat of the future primary pharyngeal membrane. At the caudal end of the head process, the cells of the head process are in direct continuation with the cells of the ectoderm of the primitive node region. Cranial to the primitive node the head process grows between ectoderm and entoderm, independent of each.

2. Soon after the anlage of the head process, its caudal end through rearrangement and growth of cells, acquires a lumen. The head process of this region differentiates to form the chordal canal. The chordal canal at no time in development extends to the cranial limit of the head process. The cranial end of the head process retains the character of a plate of cells, which fuse intimately with the underlying entoderm, so that its delimitation is for a time uncertain.

3 . The chordal canal soon after its formation, through dediscence of the ventral wall spreads out to form a chordal plate. With the dehiscence of the ventral wall of the chordal canal and the formation of a chordal plate, a cleft or split develops in the axial portion of the entoderm in the region of the chordal plate so that the lumen of the chordal canal becomes continuous with the cavity enclosed by the entoderm. This splitting of the ventral wall of the chordal canal and the underlying entoderm, in the guinea pig, takes place primarily in several regions, so that a series of discrete openings are formed, which fuse to form a longitudinally directed slit. The chordal plate is at no time definitely incorporated in the entoderm, the edges of the split entoderm, extending at all times to a greater or less degree under the borders of the chordal plate. 
4. The chordal plate is then again separated from the entoderm to form the definitive chorda dorsalis, this either by a simple undergrowth of the edges of the cleft entoderm, the edges approximating and fusing, or by undergrowth of the entoderm accompanied by a ventral folding of the borders of the chordal plate. Both of the methods of separation of the chordal plate from the entoderm may be observed in different regions of the same embryonic shield.

5. In the primitive streak region the chorda dorsalis differentiates directly from the ventral part of the ectoderm-mesoderm mass of the axial part of the primitive streak, by separation from the lateral mesoderm and from the ventral part of the neural plates; this leads to a relative and absolute shortening of the primitive streak. In the region of the primitive streak, the entoderm, in all stages of development, retains its character as an uninterrupted layer.

6. An open neurenteric canal is not developed in the guinea pig; instead a neurenteric cord, not clearly defined, leading from the ectoderm to the entoderm, in the primitive node region.

7. This final conclusion seems warranted: Since the entoderm takes no active part in the histogenesis of the head process, chordal canal, and chordal plate and since the chordal plate becomes only partially and temporarily incorporated in the entoderm; there seems no justification for classing the chorda dorsalis as an entodermal derivative. And since the head process, the anlage of the chordal canal and derived structures, has its anlage in the cranial portion of the primitive node, a region of active ectodermal cell proliferation; and since the chordal canal and plate retain their continuity with the primitive node, which serves as a growth zone; there seems justification in regarding head process-chordal canal, and derived structures, chordal plate and chorda dorsalis - as a derivative of the ectoderm in the sense that the mesoderm is derived from the ectoderm of the primitive streak region of the embryonic shield. 


\section{LITERATURE CITED}

von Beneden, Ed. 1888 Untersuchungen über die Blätterbildung, den Chordokanal und die Gastrulation bei den Säugetieren, Kaninchen und Vespertilio murinus. Verhandlung. Anat. Gessellsch., Anat. Anz., vol. 3.

Bonnet, R. 1884 Beiträge zur Embryologie der Wiederkäuer, gewonnen am Schafei. Arch. f. Anat. u. Phys., Anat. Abth.

1897 Beiträge zur Embryologie des Hundes. Anat. Hefte, vol. 9.

1901 Beiträge zur Embryologie des Hundes. Anat. Hefte, vol. 16.

Carius, F. 1888 a Ueber die Entwickelung der Chorda und der primitiven Rachenhaut bei Meerschweinchen und Kaninchen, Disscrtation.

1888 b Ueber den Kopffortsatz des Kaninchens. Sitzungrbr. d. Ges. z. Bef. d. Nat., Marburg. Quoted here from O. Hertwig.

Grosser, O. 1913 Ein menschlichen Embryo mit Chordokanal. Anat. Hefte, vol. 47.

Heape, W. 1883 The development of the mole. Quart. Jr. Microscop. Sc., vol. 23 .

Hentwig, O. 1906 Die Lchre von den Keimblättern. Handbuch der vergleichenden und experimentellen Entwickelungslehre der Wirbeltiere, vol. 1. Gustav Fischer, Jena.

Huber, G. Carl 1915 The development of the Albino rat (Mus norvegicus albinus). Memoirs of the Wistar Institute, no. 5.

Hubrecht, A. A. W. 1890 Studies in mamma ian embryology. II. The development of the germ layers of Sorex vulgaris. Quart. Jr. Microscop. Sc., vol. 31 .

Koeltiker, A. 1883 Ueber die Chordahöhle und die Bildung der Chorda beim Kaninchen. Sitzungsbr. d. Physical. med. Gesellsch., Würzburg.

Kerbel, F. 1889 Zur Entwickelungsgeschichte der Chorda bei Säugern (Meerschweinchen und Kaninchen). Arch. f. Anat. u. Phys., Anat. Abth. 1894 Studien zur Entwickelungsgeschichte des Schweines (Sus scropa domesticus). Morphol. Arbeiten, vol. 3.

1900 Die Gastrulation und die Keimblattbildung der Wirbeltiere. Ergebnisse d. Anat. u. Entwickl. vol. 10.

IsteberkÜHn, M. 1882 and 1884 Ueber die Chorda bei Saügethieren. Arch. f. Anat. u. Phys., Anat. Abth.

RanL, C. 1889 Theorie des Mesoderms. Morphol. Jahrbuch, vol. 15. 1893 Theorie des Mesoderms (Fortsetzung). Morphol. Jahrbuch, vol. 19.

Selenka, E. 1884 Studien über Entwickelungsgeschichte der Thiere. Drittes Heft. Die Blätterumkehrung im Ei der Nagethiere, Kreidel, Wiesbaden.

Spee, F. Graf. 1888 Ueber dic Entwickelungsvorgänge vom Knoten in Säugetierkeimscheiben. Anat. Anz., vol. 3.

1896 Neue Beobachtungen über sehr frühe Entwickelungsstufen des Menschen Eies. Arch. f. Anat. u. Phys., Anat. Abth.

1901 Die Implatation des Meersehweincheneies in die Uteruswand. Zeitschrift. f. Morph. u. Anthrop., vol. 3. 
Strahl, H. 1888 Durehschnitte des Area embryonalis bei säugetierembryonen. Verhand. der Anat. Gesellseh., Anat. Anz., vol. 3.

Triepel, H. 1914 Chorda dorsalis und Keimblätter. Anat. Hefte, vol. 50.

Tsukaguchi, R. 1912 Zur Entwickelungsgeschichte der Ziege (Capra Hircus). Anat. Hefte, vol. 46. 